\title{
The Cucumber vein yellowing virus Silencing Suppressor P1b Can Functionally Replace HCPro in Plum pox virus Infection in a Host-Specific Manner
}

\author{
Alberto Carbonell, Gabriela Dujovny, Juan Antonio García, and Adrian Valli \\ Centro Nacional de Biotecnología (CNB-CSIC), Campus Universidad Autónoma de Madrid, 28049 Madrid, Spain
}

Submitted 28 August 2011. Accepted 30 September 2011.

\begin{abstract}
Plant viruses of the genera Potyvirus and Ipomovirus (Potyviridae family) use unrelated RNA silencing suppressors (RSS) to counteract antiviral RNA silencing responses. HCPro is the RSS of Potyvirus spp., and its activity is enhanced by the upstream P1 protein. Distinctively, the ipomovirus Cucumber vein yellowing virus (CVYV) lacks HCPro but contains two P1 copies in tandem (P1aP1b), the second of which functions as RSS. Using chimeras based on the potyvirus Plum pox virus (PPV), we found that P1b can functionally replace HCPro in potyviral infections of Nicotiana plants. Interestingly, P1a, the CVYV protein homologous to potyviral $\mathrm{P1}$, disrupted the silencing suppression activity of $P 1 b$ and reduced the infection efficiency of PPV in Nicotiana benthamiana. Testing the influence of RSS in host specificity, we found that a P1bexpressing chimera poorly infected PPV's natural host, Prunus persica. Conversely, P1b conferred on PPV chimeras the ability to replicate locally in cucumber, CVYV's natural host. The deleterious effect of P1a on PPV infection is host dependent, because the P1aP1b-expressing PPV chimera accumulated in cucumber to higher levels than PPV expressing P1b alone. These results demonstrate that a potyvirus can use different RSS, and that particular RSS and upstream P1-like proteins contribute to defining the virus host range.
\end{abstract}

The establishment of a viral infection in a particular host plant relies on the availability of specific factors necessary for replication and spread of the virus, and on the ability of the virus to escape or counteract a series of defense layers raised by the plant. Among these antiviral barriers, innate immunity responses, which are also elicited by other plant pathogens, are triggered by broadly conserved pathogen-associated molecular patterns (PAMPs) (Soosaar et al. 2005). Moreover, doublestranded forms of viral RNA are recognized as a special PAMP by the infected plant, which activates RNA silencing pathways resulting in specific antiviral immunity (Ding 2010). In order to circumvent this defensive response, most plant viruses have

Corresponding authors: J. A. García; E-mail: jagarcia@cnb.csic.es; and A. Valli; E-mail: aav30@cam.ac.uk

Present address of A. Carbonell: Donald Danforth Plant Science Center, St. Louis, MO 63132, U.S.A.

Present address of A. Valli: Department of Plant Sciences, University of Cambridge, Downing Street, Cambridge CB2 3EA, United Kingdom.

* The $e$-Xtra logo stands for "electronic extra" and indicates that two supplementary tables and one supplementary figure are published online. evolved RNA silencing suppressors (RSS) (Burgyán 2008; Moissiard and Voinnet 2004; Roth et al. 2004; Valli et al. 2009).

The genus Potyvirus of the family Potyviridae is the largest group of plant viruses (López-Moya et al. 2009). The singlestranded RNA genome of Potyvirus spp. is translated into a large polyprotein and a truncated frameshift product, which are processed by three virus-encoded proteinases. One of these proteinases, the cysteine proteinase HCPro, was the first viral product to be recognized as an RSS (Anandalakshmi et al. 1998; Brigneti et al. 1998; Kasschau and Carrington 1998), and its RNA silencing suppression activity appears to be essential for potyviral viability (Garcia-Ruiz et al. 2010). Indeed, HCPro is a multifunctional protein that acts in several steps of the potyviral infection cycle, including viral genome amplification (Kasschau et al. 1997), cell-to-cell and long-distance spread (Cronin et al. 1995; Rojas et al. 1997), and aphid transmission (Berger et al. 1989), and is also involved in symptom expression (Gal-On and Raccah 2000; Pruss et al. 1997; Sáenz et al. 2000). The overall genomic structure of Potyvirus spp., including HCPro-coding sequences, is also conserved in other monopartite genera of the family Potyviridae. However, whereas an HCPro gene is included in the genome of Sweet potato mild mottle virus (SPMMV), the type member of the genus Ipomovirus, this gene is absent from the genome of other Ipomovirus spp. such as Cucumber vein yellowing virus (CVYV), Squash vein yellowing virus (SqVYV), and Cassava brown streak virus (CBSV) (Janssen et al. 2005; Li et al. 2008; Mbanzibwa et al. 2009). In CVYV and SqVYV, the RSS is the serine proteinase $\mathrm{P} 1 \mathrm{~b}$ that could have derived from a gene duplication of the 5'-terminal gene that codes for the protein P1 (Mbanzibwa et al. 2009; Valli et al. 2006). These P1b proteins, together with the single $\mathrm{P} 1 \mathrm{~s}$ of some Ipomovirus, Brambyvirus, and Poacevirus (or Susmovirus) spp., form a group of P1 homologs distinct from the typical P1 proteins of Potyvirus spp. and the first P1 copies, named P1a, of CVYV and SqVYV (Fellers et al. 2009; Susaimuthu et al. 2008; Tatineni et al. 2009; Valli et al. 2007). Interestingly, although the Tritimovirus spp. and SPMMV have HCPro, their silencing suppression activity is provided by their P1b-like P1 proteins rather than by HCPro (Giner et al. 2010; Stenger et al. 2007). Moreover, whereas the silencing suppression mechanism of potyviral HCPro and CVYV P1b appears to involve small interfering (si)RNA sequestration (Lakatos et al. 2006; Valli et al. 2011), SPMMV P1 inhibits RNA silencing by Argonaute binding (Giner et al. 2010). Thus, viruses of the family Potyviridae can use RSS with unrelated sequences and different mechanisms of action to counteract antiviral silencing and facilitate viral infection. 
In the present study, we have shown that, although RNA silencing suppression is an essential activity for Potyvirus spp., a particular potyviral infection does not depend on a unique RSS. In addition, our data suggest that specific RSS play a significant role in potyviral host range determination.

\section{RESULTS}

\section{P1b from CVYV can functionally replace HCPro} in a PPV infection.

HCPro and P1b are sequence-unrelated RSS used by Potyvirus spp. and some Ipomovirus spp., respectively, of the family Potyviridae. To test the ability of CVYV P1b to support a potyviral infection, the HCPro coding sequence of the potyvirus Plum pox virus (PPV) was replaced by that of CVYV P1b in the infectious cDNA clone pICPPV-NK-GFPn, which also expresses the green fluorescent protein (GFP) to monitor the viral infection. For simplicity, these clones are named here according the $\mathrm{N}$-terminal regions of their polyproteins (P1HC and P1P1b) (Fig. 1).

Nicotiana benthamiana and $N$. clevelandii plants were biolistically inoculated with the different cDNA clones, and the infection was tracked by monitoring the inoculated plants under visible and UV light. The chimeric PPV expressing P1b showed in both plant species a high infectivity rate (usually $100 \%$ ), similar to that of wild-type PPV expressing HCPro. However, there was a small delay of 1 to 2 days in the appearance of symptoms and GFP fluorescence in upper noninoculated leaves of plants infected with the P1b-expressing P1P1b virus with respect to plants infected with wild-type P1HC. Both P1P1b and P1HC caused systemic chlorotic mottling in $N$. clevelandii and $N$. benthamiana but these symptoms were more intense in plants infected with the P1b-expressing virus. In addition, $N$. benthamiana plants infected with P1P1b showed striking leaf distortion and edge curling but were notably less stunted than those infected with P1HC (Fig. 2). Although visi-
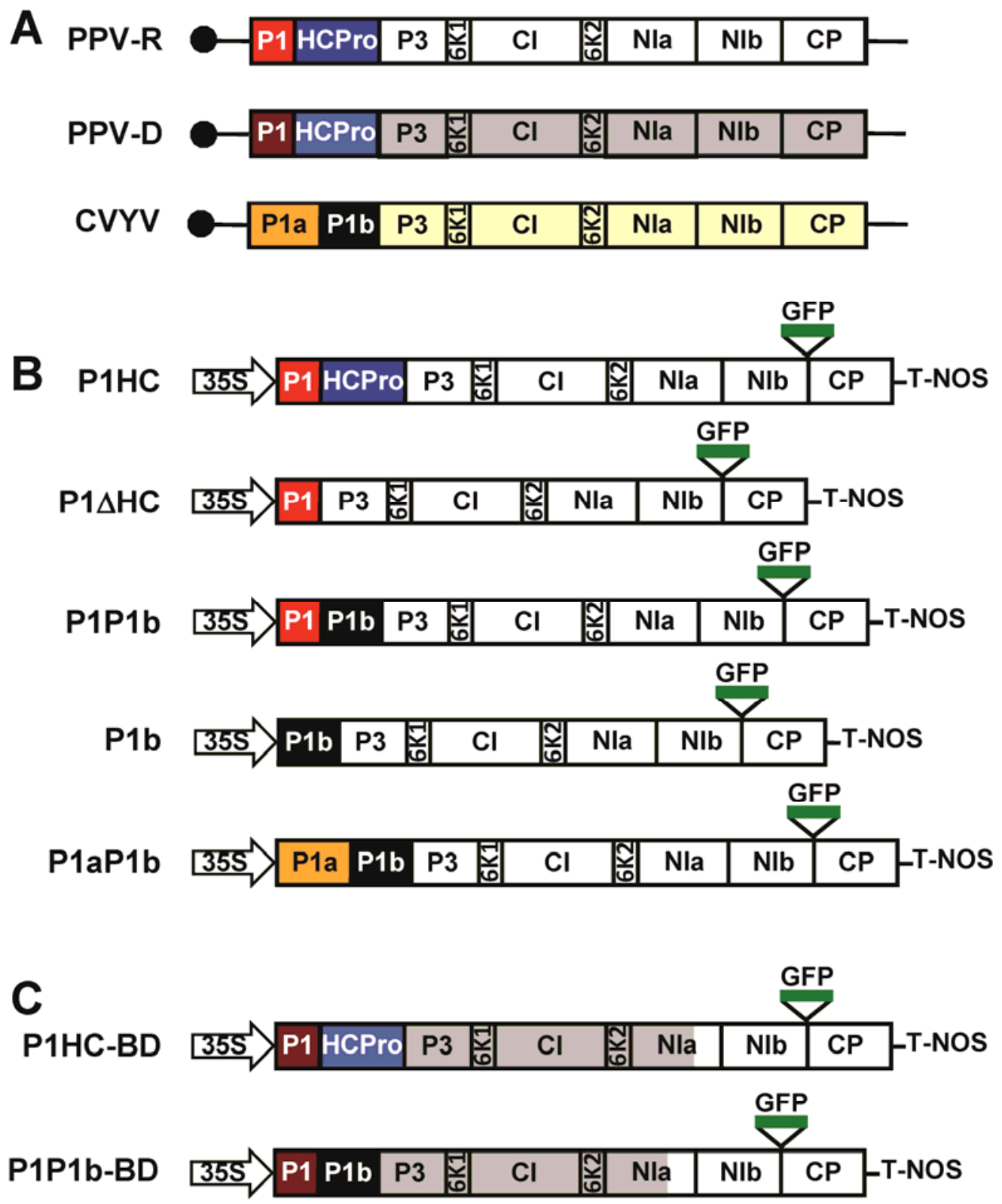

Fig. 1. Schematic representation of full-length cDNA clones derived from Plum pox virus (PPV) and Cucumber vein yellowing virus (CVYV). A, Genome maps of the PPV R and D isolates and CVYV. B, Chimeric full-length cDNA clones derived from pICPPV-NK-green fluorescent protein (GFP) employed to infect herbaceous hosts. C, Chimeric cDNA clones derived from pICPPV5'BD-GFP employed to infect Prunus persica. The coding sequence of the GFP protein inserted between the NIb and coat protein $(\mathrm{CP})$ cistrons is represented with a green rectangle. 
ble symptoms were more prominent in leaves of P1P1b-infected plants, the virus-derived GFP fluorescence was less intense in these plants than in those infected with P1HC. Western blot analysis of leaf extracts showed high accumulation levels of viral coat protein $(\mathrm{CP})$ in $\mathrm{P} 1 \mathrm{P} 1 \mathrm{~b}$-infected $N$. clevelandii and $N$. benthamiana plants but somewhat lower levels than those detected in extracts from plants inoculated with P1HC (Fig. 2). Immunoreactions with anti-P1b- and anti-HCPro-specific antibodies confirmed that each virus expressed the expected RSS (Fig. 2). These results indicate that CVYV P1b can functionally replace HCPro in a PPV infection.

\section{Relevance of P1 and P1a proteins}

\section{in P1b-expressing PPV chimeras.}

Some reports suggest that the potyviral P1 protein enhances the activity of the RSS HCPro (Anandalakshmi et al. 1998; Kasschau and Carrington 1998; Pruss et al. 1997; Rajamaki et al. 2005; Valli et al. 2006). We were interested in knowing whether P1a, the homologous protein of P1 in CVYV, has a similar effect on P1b activity in the context of a viral infection, and whether the natural CVYV P1a-P1b combination could be more effective than the chimeric PPV P1-CVYV P1b one. With this aim, we engineered the GFP-tagged recombinant viruses $\mathrm{P} 1 \mathrm{aP} 1 \mathrm{~b}$ and $\mathrm{P} 1 \mathrm{~b}$, in which the P1-HC sequence of PPV was replaced by either P1a-P1b or P1b from CVYV (Fig. 1). Leaves of $N$. benthamiana plants were biolistically inoculated with the different constructs, and the infection was monitored under visible and UV lights. $\mathrm{P} 1 \mathrm{~b}$ and $\mathrm{P} 1 \mathrm{aP} 1 \mathrm{~b}$ chimeras showed high infectivity levels similar to those of P1HC and P1P1b. However, whereas plants infected with either P1P1b or P1b viruses showed similar disease symptoms, which appeared with a small delay (1 to 2 days) with respect to P1HC-infected plants, plants inoculated with $\mathrm{P} 1 \mathrm{aP} 1 \mathrm{~b}$ showed no visible symptoms (data not shown). At 3 weeks postinoculation, the spread of green fluorescence in upper noninoculated leaves close to the inoculated ones was more limited in the P1b-infected plants than in plants infected with P1P1b (Fig. 3A). However, PPV $\mathrm{CP}$ accumulation in regions showing green fluorescence was similar in plants infected with $\mathrm{P} 1 \mathrm{~b}$ or $\mathrm{P} 1 \mathrm{P} 1 \mathrm{~b}$, and only slightly lower than in P1HC-infected plants (Fig. 3A). In contrast, at this time, green fluorescence was very faint in the upper noninoculated leaves of plants infected with $\mathrm{P} 1 \mathrm{aP} 1 \mathrm{~b}$, which showed

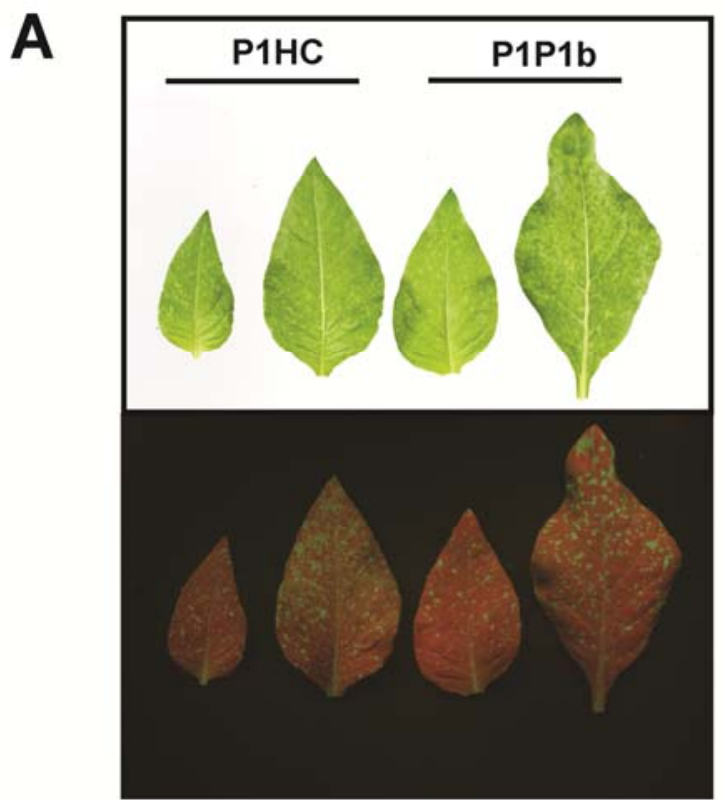

N. clevelandii

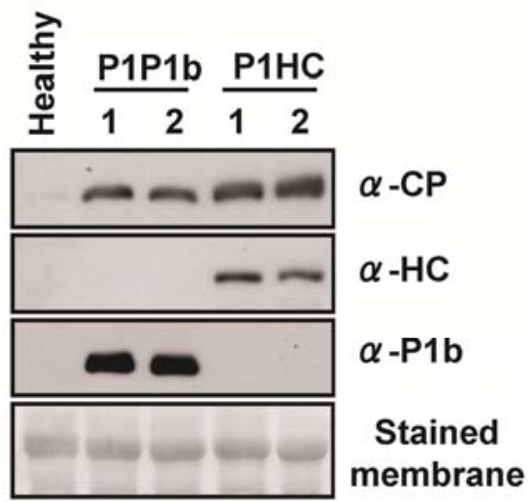

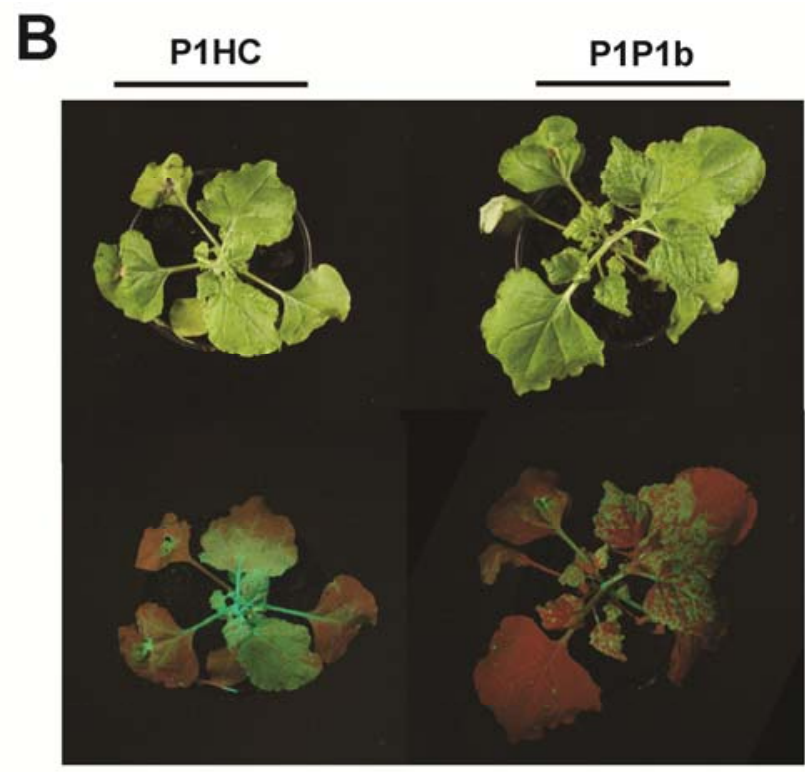

N. benthamiana

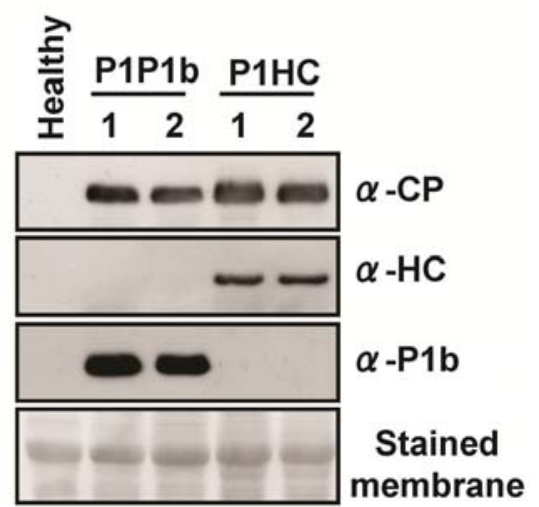

Fig. 2. P1P1b, a chimerical Plum pox virus (PPV) in which HCPro was replaced by Cucumber vein yellowing virus (CVYV) P1b, is able to infect Nicotiana clevelandii and $N$. benthamiana plants. Top panels: symptoms and green fluorescent protein (GFP) expression of plants infected with the P1P1b chimera or with the wild-type PPV (P1HC). Pictures of A, detached $N$. clevelandii upper noninoculated leaves and $\mathbf{B}$, whole $N$. benthamiana plants taken under visible (upper row) or UV illumination with a hand lamp (lower row) at 21 days postinoculation (dpi). Bottom panels: Western blot analysis of systemically infected leaves from two plants collected at 21 dpi. Polyclonal sera specific for coat protein (CP) and HCPro of PPV, and CVYV P1b, were used for the immunodetections. The membrane stained with Ponceau red showing the Rubisco is included as a loading control. 
lower accumulation levels of viral $\mathrm{CP}$ compared with plants infected with the rest of viruses (Fig. 3A).

At 21 days postinoculation (dpi), the apical young leaves of plants infected with either $\mathrm{P} 1 \mathrm{~b}$ or $\mathrm{P} 1 \mathrm{aP} 1 \mathrm{~b}$ viruses did not show green fluorescence, and the green fluorescence of the corresponding leaves of P1P1b-infected plants was much fainter than that observed in P1HC-infected plants (Fig. 3A). This fact suggested that a recovery from infection could be starting in plants infected with viruses lacking HCPro, mainly when P1 was also absent. To assess this possibility, the infected plants were ana- lyzed at later stages (36 dpi). Whereas young leaves of plants infected with P1HC or P1P1b showed viral symptoms, the apical leaves of plants infected with $\mathrm{P} 1 \mathrm{~b}$ and $\mathrm{P} 1 \mathrm{aP} 1 \mathrm{~b}$ appeared healthy (Fig. 3B). In agreement with this observation, green fluorescence was apparent in young leaves of plants infected with $\mathrm{P} 1 \mathrm{HC}$ and, with less intensity, in those from P1P1b-infected plants, but it could not be detected in young leaves of plants infected with $\mathrm{P} 1 \mathrm{~b}$ or P1aP1b (Fig. 3B). A Western blot analysis showed that, in older $(+5$ and +6$)$ and intermediate $(+7$ and +8$)$ leaves (where " + " indicates the position above the inoculated
A

Whole

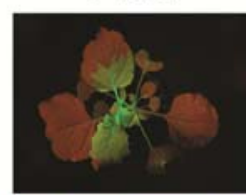

$+2$

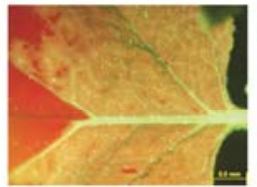

$+3$

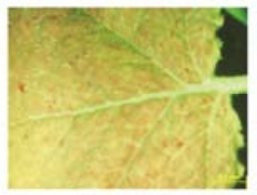

Apical

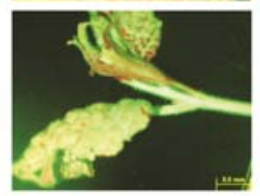

B
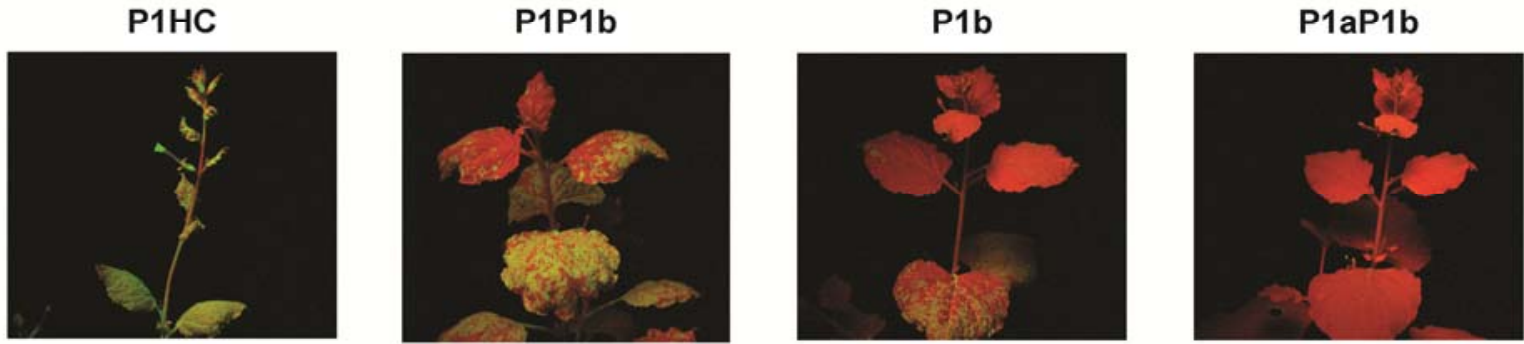

Younger Leaves

$+9,+10$

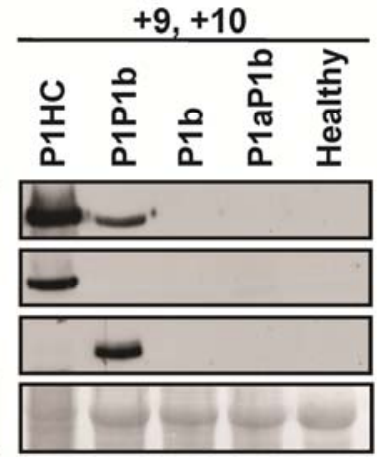

Intermediate Leaves

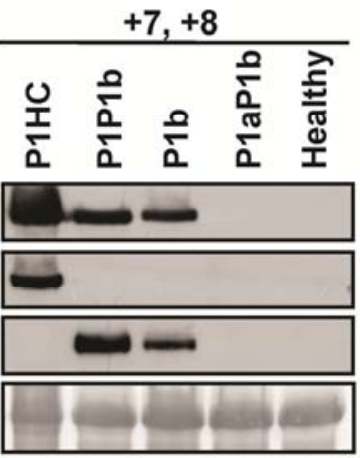

Older Leaves

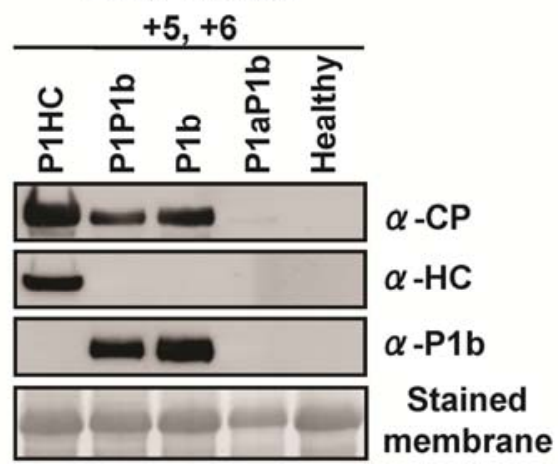

Fig. 3. Infection of Plum pox virus (PPV) chimeric viruses expressing Cucumber vein yellowing virus (CVYV) P1b in Nicotiana benthamiana. A, Patterns of infection at 21 days postinoculation (dpi). Green fluorescent protein (GFP) fluorescence pictures taken under a UV hand lamp of whole infected plants, or under a epifluorescence microscope of the second $(+2)$ and third $(+3)$ leaves above the inoculated one, and the most apical leaves are shown in the left panels. Western blot analysis of pools of tissue showing GFP expression of systemically infected leaves $(+2$ and +3$)$ from two plants is shown in the left panels. B, Patterns of infection at 36 dpi. Pictures showing GFP fluorescence under a UV hand lamp of whole infected plants are shown in the top panels. Western blot analysis of pools of tissue showing GFP expression (or the equivalent tissue from plants not showing evident green fluorescence) from young (+9 and $+10)$, intermediate $(+7$ and +8$)$, or old $(+5$ and +6$)$ upper noninoculated leaves of two plants is shown in the bottom panels. A polyclonal serum specific for PPV coat protein (CP) was used for assessment of virus accumulation. Immunoreactions with polyclonal sera specific for PPV HCPro and CVYV P1b confirmed the identity of the infecting viruses. Membranes stained with Ponceau red showing the Rubisco are included as loading controls. 
leaves), the $\mathrm{CP}$ accumulation levels of plants infected with $\mathrm{P} 1 \mathrm{~b}$ or P1P1b were similar and only slightly lower than those of P1HC-infected plants, similar to the +2 and +3 leaves analyzed at 21 dpi (Fig. 3A). In contrast, no viral $\mathrm{CP}$ was detected in young leaves $(+9$ and +10 ) of plants infected with $\mathrm{P} 1 \mathrm{~b}$, and $\mathrm{CP}$ accumulation was notably lower in the corresponding leaves of plants infected with P1P1b than in those of P1HC-infected plants (Fig. 3B). At this time, viral CP was detected only in the older leaves of P1aP1b-infected plants and at extremely low levels (Fig. 3B), reinforcing the idea that the combination of P1a and P1b supports PPV infection very poorly, and plants recover easily from P1aP1b infection. We also substituted PPV P1 by CVYV P1a in the wild-type, HCPro-containing, PPV clone. The resulting chimera, P1aHC, infected $N$. benthamiana as badly as P1aP1b (Supplementary Fig. S1), demonstrating that P1a is also nonfunctional when the virus is using HCPro as RSS.

Together, these results indicate that, despite P1 being dispensable to establish the infection of a chimeric PPV carrying CVYV P1b instead of HCPro, P1 might be necessary to prevent recovery from infection, and CVYV Pla cannot replace PPV P1 in this task.

The silencing suppression activity of P1b is essential for its ability to replace HCPro in the PPV infection.

In order to assess the relevance of P1b-mediated silencing suppression in the context of a potyviral infection, we constructed two variants of the P1P1b chimera containing either the RK68,69AA or the C89A mutation, which affect the conserved LxKA motif or a putative $\mathrm{Zn}$ finger, respectively, and abolish the
RNA silencing suppression activity of CVYV P1b (Valli et al. 2008). The C93A mutation, which does not affect the P1b silencing suppression activity, was engineered in a control PPV P1P1b clone. In addition, a PPV cDNA construct lacking HCPro (P1 $\Delta \mathrm{HC})$ was also generated (Fig. 1). N. benthamiana plants were biolistically inoculated with DNA of these PPV clones, and the infection process was followed by monitoring GFP fluorescence and symptom expression. Whereas systemic disease symptoms and green fluorescence were observed in plants inoculated with viruses carrying an active RSS (P1HC, P1P1b, and P1P1b C93A), no visual signs of local or systemic infection were detected in those plants inoculated with clones that do not encode a known RSS (P1 $\Delta \mathrm{HC})$, or code for inactive P1b mutants (P1P1b RK68,69AA or P1P1b C89A) (Fig. 4A).

Western blot analyses of protein extracts from inoculated and upper noninoculated leaves confirmed the visual observations, and showed no viral CP accumulation in plants inoculated with P1P1b RK68,69AA, P1P1b C89A, or P1 $\Delta \mathrm{HC}$, whereas large amounts of viral $\mathrm{CP}$ were detected in plants inoculated with clones expressing active RSS (P1HC, P1P1b, and P1P1b C93A) (Fig. 4B). These results indicate that the RNA silencing suppression activity provided by either HCPro or P1b is essential to support PPV infection.

\section{CVYV P1a but not PPV P1 interferes} with the RNA silencing suppression activity of CVYV P1b in agroinfiltration assays.

To assess the contribution of differences in antisilencing activities to the specific biological features of the different PPV

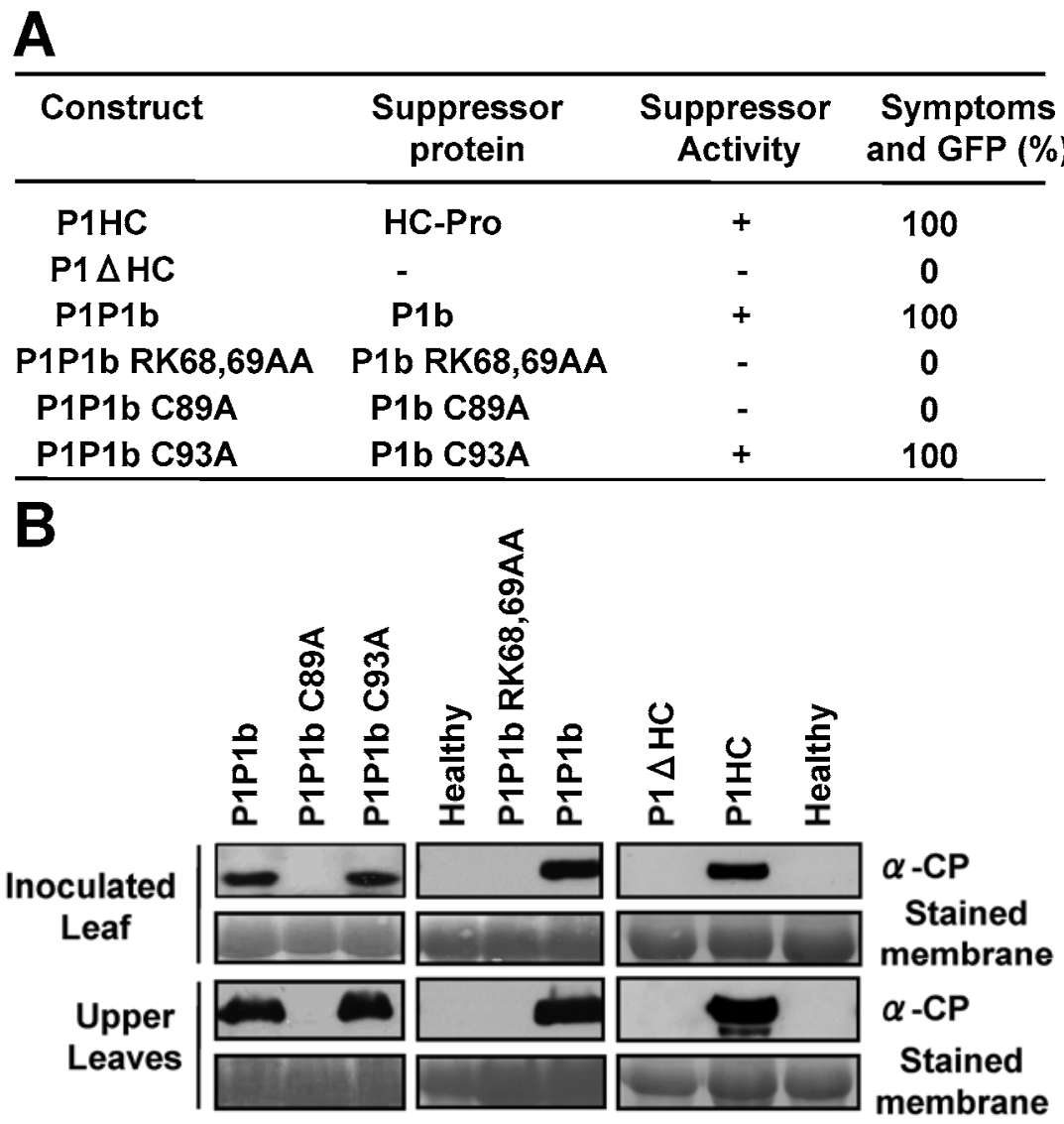

Fig. 4. Plum pox virus (PPV) requires an active RNA silencing suppressor (RSS) to infect Nicotiana benthamiana. A, Result of visual inspection of N. benthamiana plants inoculated with PPV cDNA clones differing in their encoded RSS. RNA silencing suppression activity was estimated from published information (Valli et al. 2006, 2008). B, Western blot analysis of leaf extracts from pools of either inoculated (7 days postinoculation [dpi]) or upper (21 dpi) leaves of four $N$. benthamiana plants inoculated with the indicated cDNA clones. A polyclonal serum specific for PPV coat protein (CP) was used for the immunodetection. Membranes stained with Ponceau red showing the Rubisco are included as loading controls. 
$A_{p 35 S: G F P}$ p5S GFP-T-NOS
p35S:GF-IR 35S GF 19 T-NOS

pBIN-19
(vector)

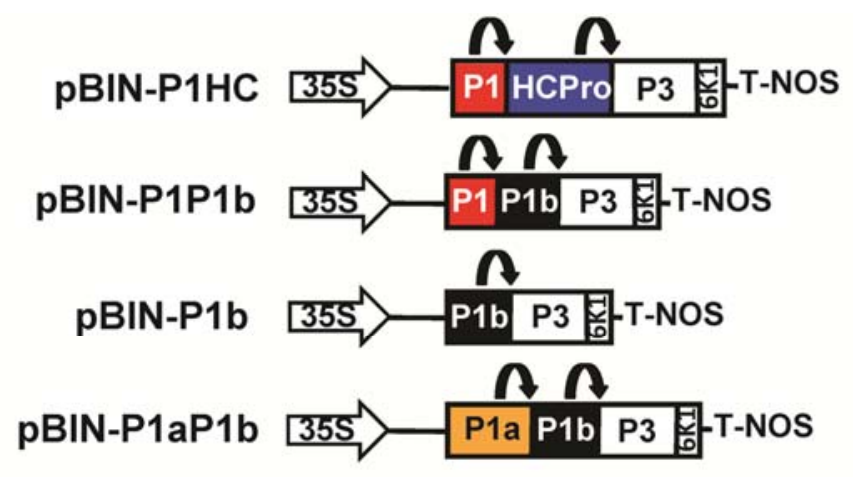

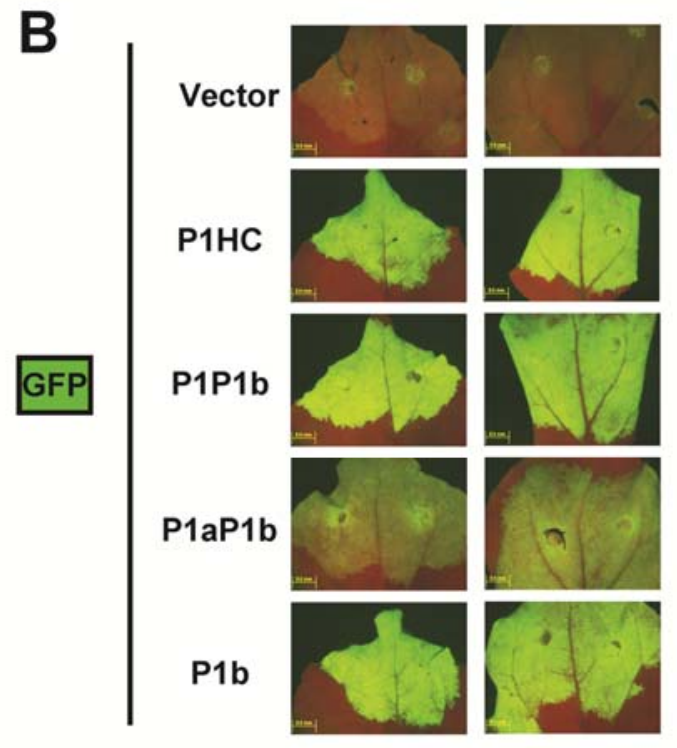
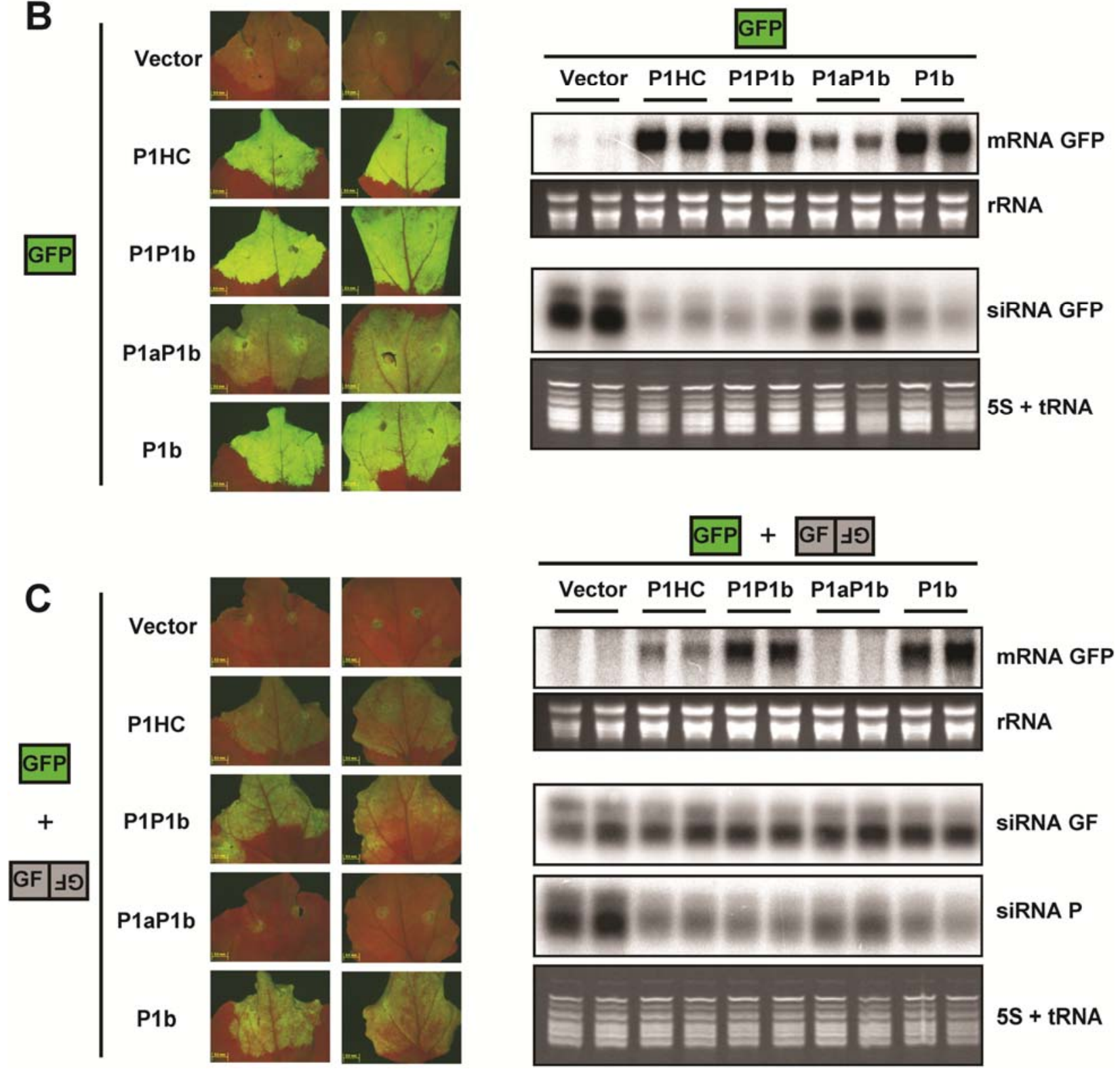

Fig. 5. RNA silencing suppression activity of the N-terminal regions of the genomic polyproteins of Plum pox virus (PPV) chimeras containing Cucumber vein yellowing virus (CVYV) P1b. A, Schematic representation of the green fluorescent protein (GFP) and viral-derived constructs used in the RNA silencing assays. Black arrows indicated the auto-proteolitic processes mediated by P1 and HCPro from PPV, and P1a and P1b from CVYV, to produce the corresponding free proteins. B, Single-stranded RNA-triggered silencing assay. C, Double-stranded RNA-triggered silencing assay. B and C, Left panels show GFP fluorescence pictures of leaves from two independent plants taken under an epifluorescence microscope at 6 days post-agroinfiltration (dpa), and right panels show Northern blot analyses of GFP mRNA and small interfering (si)RNA extracted at 6 dpa from leaf patches of two plants infiltrated with agrobacteria carrying the plasmid indicated above each lane. Two different probes were used for detection of GFP siRNAs: the GF probe (for primary plus secondary siRNAs) corresponds to the GFP fragment included in the inverted repeat (IR) RNA encoded by the silencing trigger plasmid p35S:GF-IR, and the P probe (specific for secondary siRNAs) corresponds to the 3' terminal region of the GFP gene, which is not included in p35S:GF-IR. EtBr-stained rRNA and 5S+tRNA are shown as loading controls for the blots of mRNAs and siRNAs, respectively. 
chimeras, silencing suppression assays were conducted in an agroinfiltration system in $N$. benthamiana. cDNA fragments corresponding to the $5^{\prime}$ proximal region of the genomic RNAs of the different chimeras were cloned in pBin 19 under the control of the Cauliflower mosaic virus (CaMV) 35S promoter (Fig. 5A), and used for transient expression in N. benthamiana plants by infiltration with Agrobacterium tumefaciens. For simplicity, we refer to each A. tumefaciens strain by the plasmid it carries.

A sense RNA-triggered silencing assay was performed by agroinfiltration of p35S:GFP, expressing GFP mRNA as both silencing trigger and reporter (Fig. 5A). Very weak green fluorescence was observed at 6 days post-agroinfiltration (dpa) in leaf patches co-infiltrated with p35S:GFP plus an empty control plasmid as a consequence of RNA silencing induction (Fig. 5B). Co-infiltration with p35S:GFP plus plasmids expressing either $\mathrm{P} 1-\mathrm{HC}, \mathrm{P} 1-\mathrm{P} 1 \mathrm{~b}$, or $\mathrm{P} 1 \mathrm{~b}$ prevented the induction of silencing, and green fluorescence remained strong at $6 \mathrm{dpa}$ (Fig. 5B). Patches co-infiltrated with pBIN-P1aP1b also displayed green fluorescence at 6 dpa but with less intensity than patches expressing P1-HC, P1-P1b, or P1b (Fig. 5B), suggesting that the presence of $\mathrm{P} 1$ a disturbed the antisilencing activity of P1b in this assay. Consistent with these observations, Northern blot analyses showed high levels of GFP mRNA in leaves expressing $\mathrm{P} 1-\mathrm{HC}, \mathrm{P} 1-\mathrm{P} 1 \mathrm{~b}$, or $\mathrm{P} 1 \mathrm{~b}$, which were much reduced in leaves expressing P1a-P1b and extremely reduced in leaves not expressing an RSS (Fig. 5B). Concomitantly, the large amounts of GFP siRNAs caused by RNA silencing were only slightly affected by $\mathrm{P} 1 \mathrm{a}-\mathrm{P} 1 \mathrm{~b}$ expression but markedly reduced by the expression of P1-HC, P1-P1b, or P1b (Fig. 5B).

We also analyzed the anti-silencing activity of the RSS encoded by the different PPV chimeras in an inverted repeat (IR)-triggered silencing assay. This is a more stringent silencing procedure, because it does not depend on the activity of plant RNA-dependent RNA polymerases, and could be more sensitive to small differences in the silencing suppression activity of the different RSS compared with the sense-triggering assay. We expressed p35S:GFP as reporter and p35S:GF-IR, which codes for an IR of a 5'-terminal fragment (GF) of the GFP RNA, as silencing trigger (Fig. 5A). Fluorescence monitoring and Northern blot analysis showed that GF-IR triggered a fast and strong silencing of the reporter GFP mRNA, which was not counteracted by P1a-P1b expression (Fig. 5C). P1$\mathrm{HC}, \mathrm{P} 1-\mathrm{P} 1 \mathrm{~b}$, and P1b were able to suppress the RNA silencing triggered by GF-IR but GFP fluorescence and GFP mRNA accumulation were higher in leaves expressing $\mathrm{P} 1-\mathrm{P} 1 \mathrm{~b}$ or $\mathrm{P} 1 \mathrm{~b}$ than in those expressing $\mathrm{P} 1-\mathrm{HC}$, suggesting that $\mathrm{P} 1 \mathrm{~b}$ could be a suppressor stronger than HCPro in this assay (Fig. 5C). A Northern blot analysis of small RNAs showed that the accumulation of primary GF siRNAs, which are expected to be produced by DCL-mediated cleavage of GF-IR, was not affected by the expression of the RSS (Fig. 5C). In contrast, the levels of secondary (P) siRNAs, produced by transitive silencing outside the GF trigger, were reduced in the presence of suppressors (Fig. 5C, right). The decrease in the accumulation of secondary P siRNAs was observed, although less pronounced than in leaves expressing other suppressor constructs, even in leaves expressing P1a-P1b, which did not accumulate appreciable amounts of GFP mRNA (Fig. 5C).

\section{Incomplete self-cleavage activity of CVYV P1a in N. benthamiana.}

The results shown in Figure 5 demonstrate that upstream P1a sequences drastically interfere with the RNA silencing suppression activity of CVYV P1b. Similarly, the silencing suppression activity of P1a-HC was much lower than that of P1-HC. In contrast, P1 has been shown to enhance the silenc- ing suppression activity of PPV HCPro (Valli et al. 2006). However, P1 starts to have an interfering effect when its selfcleavage activity is disturbed and $\mathrm{P} 1 \mathrm{HC}$ remains unprocessed (J. M. Viedma, A. Valli, J. A. García, and C. Simon-Mateo, unpublished results). The low silencing suppression activity of P1a-P1b does not lead to enough protein accumulation to allow for a confident assessment of the self-cleavage activity of P1a in the agroinfiltration assay. Thus, P1-P1b and P1a$\mathrm{P} 1 \mathrm{~b}$ were expressed by agroinfiltration together with the strong silencing suppressor P19 from Tomato bushy stunt virus (TBSV) and GFP to easily monitor silencing suppression efficiency. Silencing suppression was highly efficient in leaves expressing either P1-P1b or P1a-P1b, together with P19, as revealed by similar strong green fluorescence and high GFP accumulation levels (Fig. 6). In contrast, the levels of accumu-
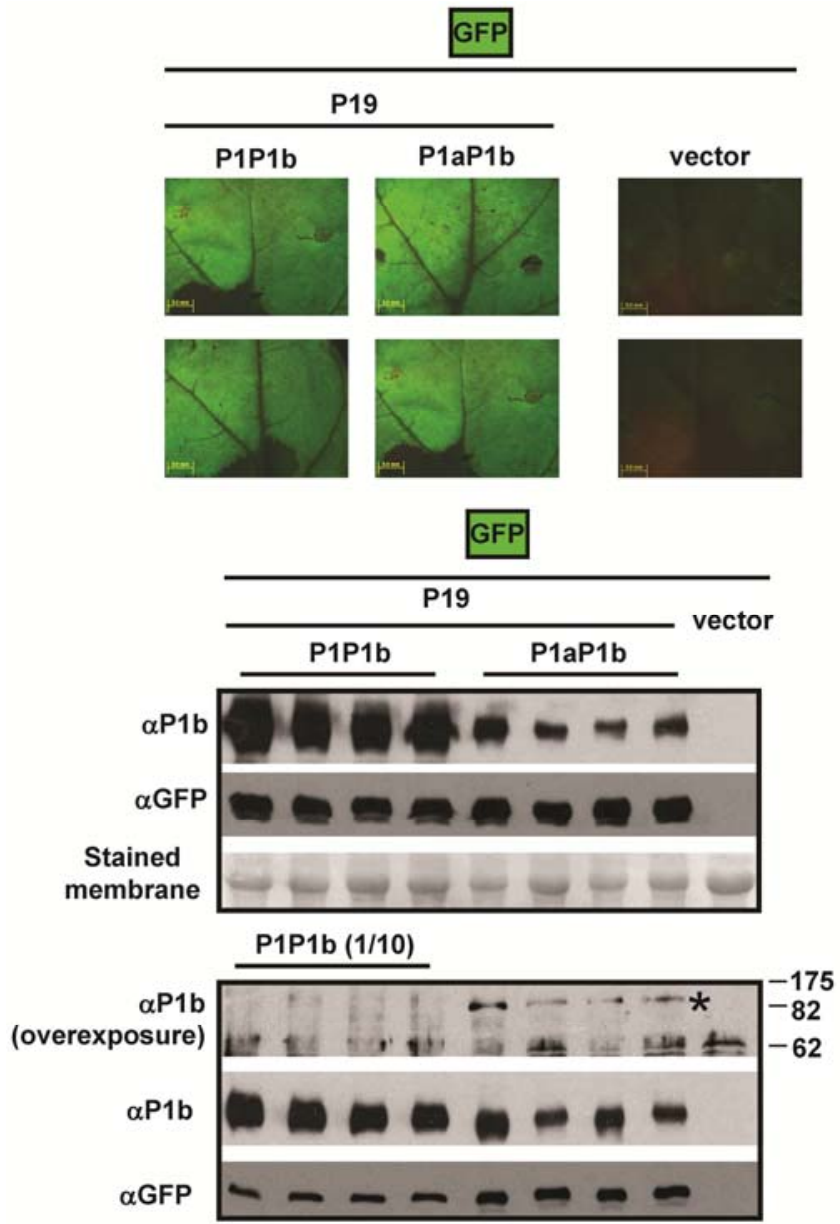

Fig. 6. Analysis of the accumulation of self-processed P1b products and unprocessed $\mathrm{P} 1 \mathrm{P} 1 \mathrm{~b}$ or $\mathrm{P} 1 \mathrm{aP} 1 \mathrm{~b}$ precursors in Nicotiana benthamiana leaves expressing $\mathrm{P} 1 \mathrm{P} 1 \mathrm{~b}$ or $\mathrm{P} 1 \mathrm{aP} 1 \mathrm{~b}$, respectively. Leaves were agroinfiltrated with Agrobacterium tumefaciens expressing green fluorescent protein (GFP), Tomato bushy stunt virus P19, and either P1P1b or P1aP1b. Leaves infiltrated with A. tumefaciens expressing GFP and empty pBIN-19 (vector) were used as a control. Upper panels show GFP fluorescence pictures of leaves from two independent plants taken under an epifluorescence microscope at 6 days post-agroinfiltration. Middle and bottom panels show Western blot analyses of $N$. benthamiana plants (two leaves per plant) infiltrated with agrobacteria carrying the plasmids indicated above each lane. Ten-times-diluted P1P1b extracts were analyzed in the bottom Western blot. Immunoreactions were conducted with the indicated antibodies. Positions of prestained molecular mass markers (New England Biolabs) (in kilodaltons) run in the same gel are indicated to the right of an overexposed anti-P1b immunoreaction. The position of the bands corresponding to unprocessed $\mathrm{P} 1 \mathrm{aP} 1 \mathrm{~b}$ is indicated by an asterisk. The membrane stained with Ponceau red showing the Rubisco is included as a loading control. 
lation of P1b were more than 10 times lower in leaves expressing P1a-P1b than in those expressing P1-P1b. Moreover, in the leaves expressing $\mathrm{P} 1 \mathrm{a}-\mathrm{P} 1 \mathrm{~b}$, a faint band corresponding to a protein with the expected mobility of the unprocessed product was clearly detected. An equivalent protein could not be detected in the leaves expressing P1-P1b (Fig. 6).

This result suggests that CVYV P1a self-cleavage is incomplete, and its efficiency is lower than that of PPV P1, in N. benthamiana.

\section{A PPV-derived virus expressing P1b instead} of HCPro infects peach seedlings poorly.

To explore the contribution of RSS in determining specific host ranges, we tested the ability to infect Prunus persica (a natural host for PPV but not for CVYV) of a PPV-based chimeric virus expressing CVYV P1b, P1P1b-BD. P1P1b-BD was constructed by replacing the HCPro sequence of P1HC$\mathrm{BD}$, a PPV chimera that infects GF-305 peach seedlings efficiently (Salvador et al. 2008), with that of CVYV P1b (Fig. 1C).

\section{A}

P1HC-BD
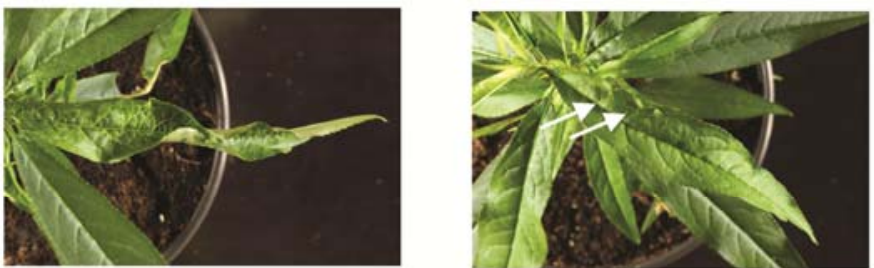

P1P1b-BD

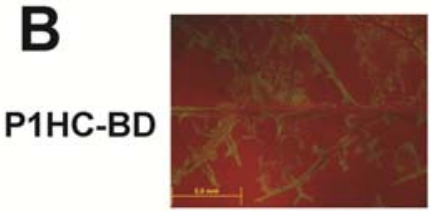

$+4$

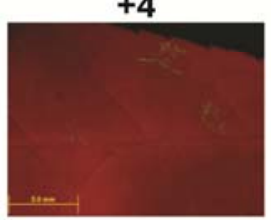

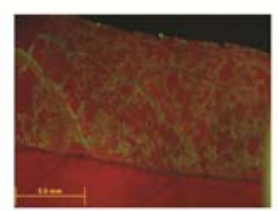

$+5$

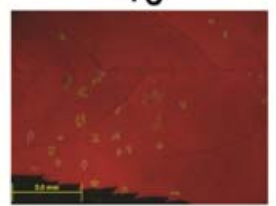

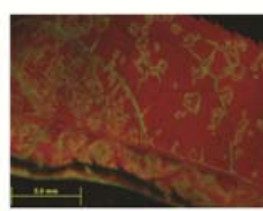

$+6$

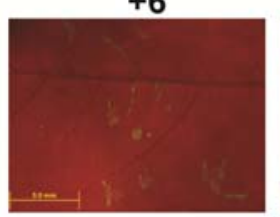

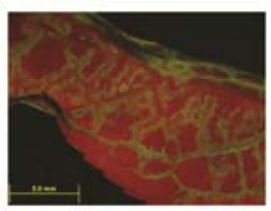

$+7$

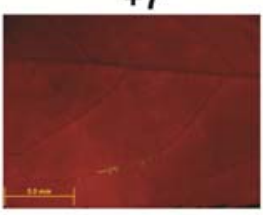

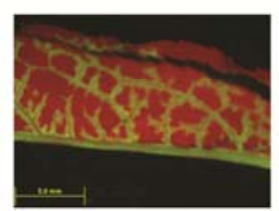

$+8$
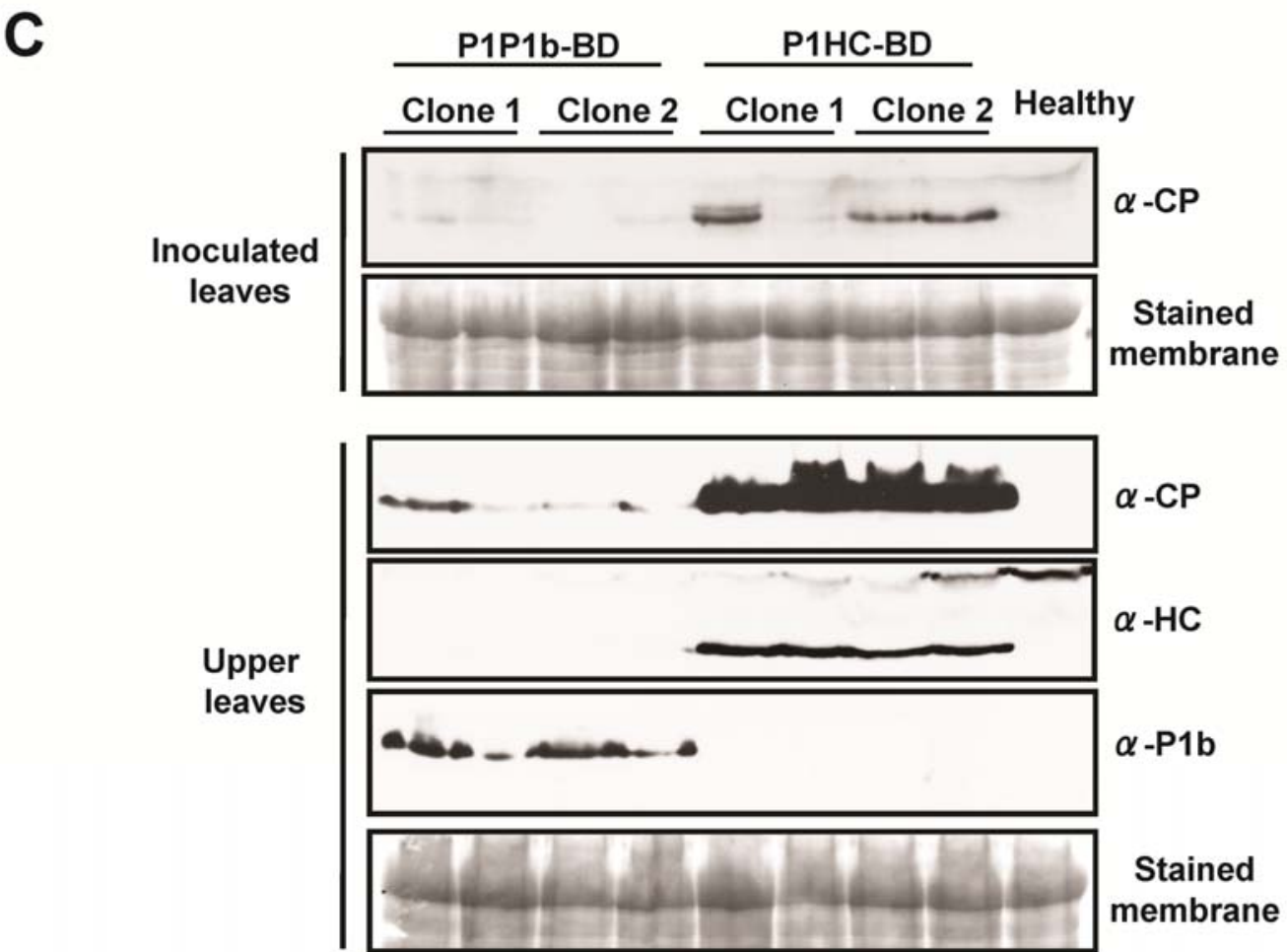

Fig. 7. Infection of GF-305 peach seedlings by a Plum pox virus (PPV)-derived virus expressing Cucumber vein yellowing virus (CVYV) P1b. A, Pictures taken under visible light at 24 days postinoculation (dpi) showing the symptoms caused by the indicated viruses in GF-305 peach seedlings. Small chlorotic regions in a leaf of the P1P1b-BD-infected plant are highlighted with white arrows. B, Pictures taken under an epifluorescence microscope at 21 dpi showing virus-derived green fluorescent protein (GFP) fluorescence in detached leaves (from position +4 to +8 above the inoculated ones) of GF-305 peach seedlings infected by the indicated viruses. C, Western blot analysis of inoculated (collected at $17 \mathrm{dpi}$ ) and upper noninoculated (collected at $24 \mathrm{dpi}$ ) leaf tissue from two GF-305 peach seedlings infected with the indicated viruses. A polyclonal serum specific for PPV coat protein (CP) was used for assessment of virus accumulation. Immunoreactions with polyclonal sera specific for HCPro of PPV and P1b of CVYV confirmed the identity of the infecting viruses. Membranes stained with Ponceau red showing the Rubisco are included as loading controls. 
Peach seedlings were biolistically inoculated with the chimeric cDNAs, and the progress of infections was monitored under visible and UV illumination. Both P1HC-BD and P1P1b-BD showed $100 \%$ infectivity; however, whereas typical PPV symptoms of leaf curling and chlorosis started at approximately 12 dpi in apical leaves of peach seedlings inoculated with P1HC$\mathrm{BD}$, infection symptoms of P1P1b-BD were much milder, consisting of small chlorotic areas, and could be detected only at approximately $21 \mathrm{dpi}$ (Fig. 7A). Moreover, strong and widely distributed green fluorescence was observed in leaves of P1HCBD-infected plants, whereas leaves of seedlings infected with P1P1b-BD displayed very weak fluorescence in small spots (Fig. 7B).

Western blot analyses detected noticeable levels of viral $\mathrm{CP}$ in the bombarded leaves of almost all the plants inoculated with P1HC-BD, whereas no or a very low amount of $\mathrm{CP}$ was detected in leaves inoculated with P1P1b-BD (Fig. 7C). Similar analyses showed high levels of $\mathrm{CP}$ in upper noninoculated leaves of plants infected with P1HC-BD, contrasting with the very low amount of this protein that could be detected in the upper leaves of plants infected with P1P1b-BD (Fig. 7C).

\section{CVYV P1b confers on PPV the ability}

to infect cucumber locally.

To further explore the contribution of RSS to host specificity, we tested the infectivity of HCPro- and P1b-expressing PPV variants in Cucumis sativus, a natural host of CVYV, which has not been reported to be susceptible to PPV infection. Preliminary experiments showed that cucumber leaves were particularly sensitive to the microparticle bombardment method, because leaves were considerably damaged after the bombardment. Therefore, we selected agroinfiltration as the inoculation procedure for the cucumber experiments because it caused less damage to the inoculated leaf, and it is expected to maintain local expression for longer periods. The full-length cDNA sequences of P1HC, P1P1b, P1b, and P1aP1b were engineered in $\mathrm{pBin} 19$-derived plasmids. A. tumefaciens strains transformed with these plasmids were used to inoculate $C$. sati$v u s$ and $N$. benthamiana plants. The infection process was monitored by careful inspection of green fluorescence. Cucumber leaves inoculated with either $\mathrm{P} 1 \mathrm{HC}$ or the empty vector displayed a similar yellow fluorescence as a consequence of the leaf damage caused by the infiltration procedure (Fig. 8A). However, although GFP fluorescence could not be detected in P1HC-inoculated cucumber leaves, a strong GFP expression was observed in $N$. benthamiana leaves inoculated with the same Agrobacterium culture (Fig. 8A). In contrast, distinct green fluorescent foci were detected around the damaged tissue displaying yellow fluorescence in all cucumber leaves inoculated with the three PPV-derived chimeras expressing CVYV P1b (Fig. 8A). Interestingly, the green fluorescence foci were quite similar in cucumber leaves inoculated with either P1b, $\mathrm{P} 1 \mathrm{P} 1 \mathrm{~b}$, or P1aP1b, contrasting with the much lower intensity of the GFP signal of P1aP1b compared with P1P1b and P1b in $N$. benthamiana leaves (Fig. 8A).

Western blot analyses of infiltrated leaves confirmed the results of GFP monitoring. Hence, $N$. benthamiana leaves inoculated with P1HC accumulated PPV CP at high levels, whereas this protein was either not or hardly detected in leaves of cucumber inoculated with this virus (Fig. 8B). In contrast,

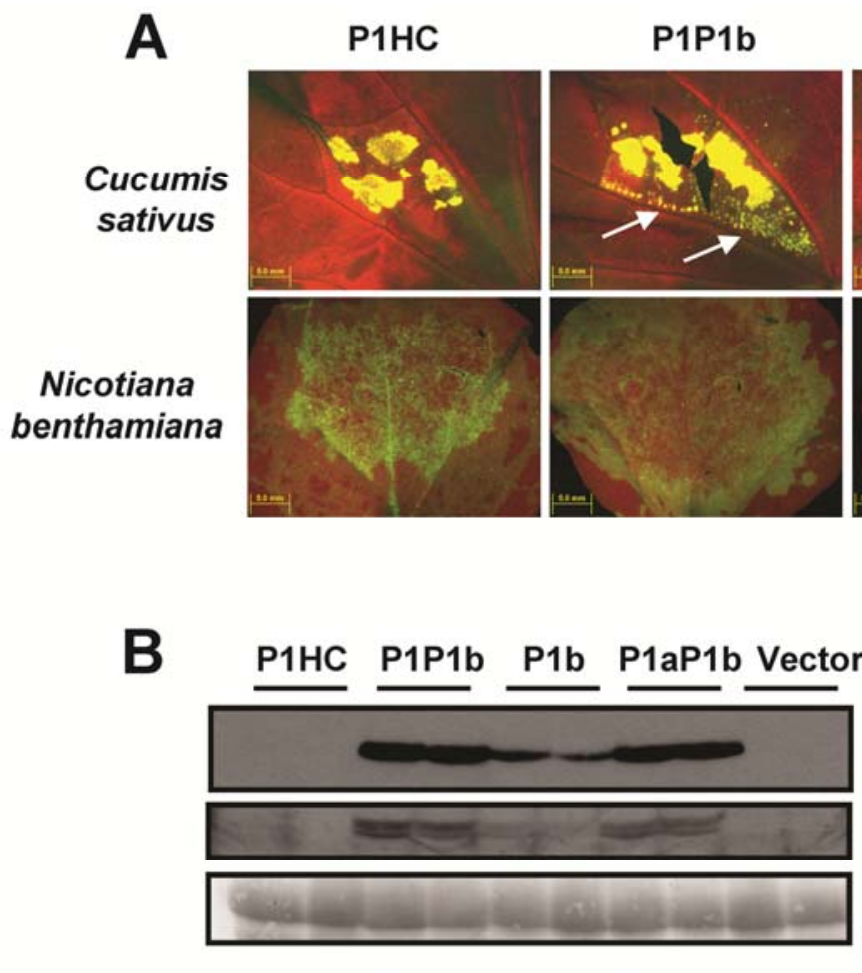

Cucumis sativus
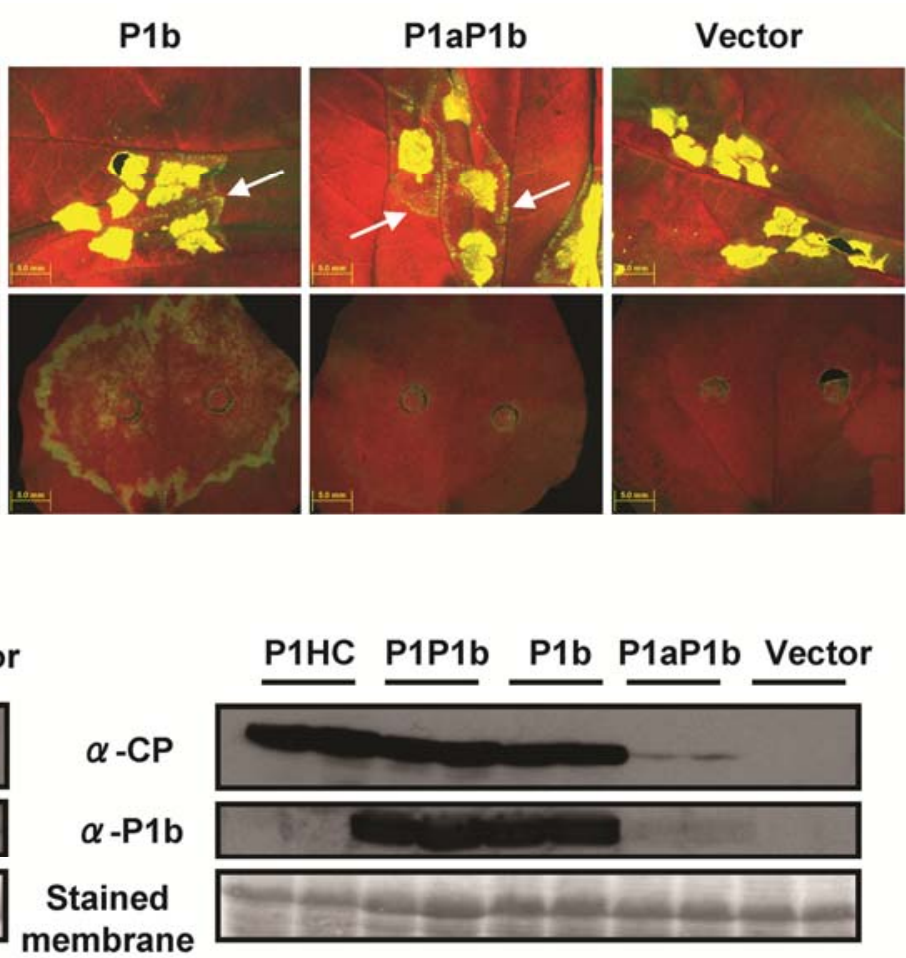

Nicotiana benthamiana

Fig. 8. Accumulation of Plum pox virus (PPV)-derived viruses expressing Cucumber vein yellowing virus (CVYV) P1b in cucumber and Nicotiana benthamiana leaves. A, Pictures taken under an epifluorescence microscope at 7 days post-agroinfiltration (dpa) showing virus-derived green fluorescent protein (GFP) fluorescence in leaves of Cucumis sativus (upper row) or N. benthamiana (lower row) infiltrated with Agrobacterium strains expressing the indicated viral full-length cDNA clones. Regions with green fluorescence foci in cucumber leaves are indicated with white arrows. B, Western blot analysis of leaf patches of two plants infiltrated with Agrobacterium strains expressing the indicated viral full-length cDNA clones. Samples were collected at 7 dpa. A polyclonal serum specific for PPV coat protein (CP) was used for assessment of virus accumulation. Immunoreactions with a polyclonal serum specific for CVYV P1b confirmed the identity of the infecting viruses. Membranes stained with Ponceau red showing the Rubisco are included as loading controls. 
PPV CP was detected in cucumber leaves inoculated with P1b, $\mathrm{P} 1 \mathrm{P} 1 \mathrm{~b}$, or $\mathrm{P} 1 \mathrm{aP} 1 \mathrm{~b}$, which differ in producing high (P1b and $\mathrm{P} 1 \mathrm{P} 1 \mathrm{~b})$ or very low (P1aP1b) amounts of viral CP in N. benthamiana (Fig. 8B). It is also noteworthy that, in cucumber leaves, the $\mathrm{CP}$ of both $\mathrm{P} 1 \mathrm{P} 1 \mathrm{~b}$ and $\mathrm{P} 1 \mathrm{aP} 1 \mathrm{~b}$ viruses appear to accumulate at a higher level than that of the P1b virus. Together, these results indicate that the replacement of PPV HCPro by CVYV P1b is crucial for proper PPV replication in cucumber but not in $N$. benthamiana and that, although the presence of CVYV P1a has a strong negative effect on PPV infection in $N$. benthamiana, both this protein and PPV P1 could facilitate PPV replication in cucumber.

On the other hand, whereas all PPV variants agroinoculated into $N$. benthamiana plants were able to establish a systemic infection, GFP fluorescence and CP accumulation were detected in neither the inoculated leaves outside the infiltration area nor the upper noninoculated leaves of cucumber plants agroinoculated with HCPro- or P1b-expressing PPV chimeras (data not shown), indicating that CVYV P1b alone is not enough to confer on PPV the ability to spread away from the initial infection foci in cucumber.

\section{DISCUSSION}

Previous studies have demonstrated that viruses of the family Potyviridae use different proteins to counteract antiviral RNA silencing. Here, we show that a heterologous RSS, CVYV P1b, can functionally replace HCPro in the infection of the potyvirus PPV, affecting its host specificity and symptomatology. We also show that the presence in the viral genome of different P1 genes upstream from the RSS coding sequence conditions the phenotype of the P1b-expressing PPV chimeras.

Diverse engineered viruses lacking their RSS have been constructed and well characterized, such as the Tombusvirus spp. Cymbidium ringspot virus and TBSV lacking P19 (Omarov et al. 2006; Qiu et al. 2002; Szittya et al. 2002) and 2b-deletion mutants of the cucumovirus Cucumber mosaic virus (DiazPendon et al. 2007; Ziebell et al. 2007). These mutants were able to initiate the infection process and reach upper noninoculated leaves but resulted in attenuated infections characterized by milder symptoms and recovery phenotypes caused by antiviral RNA silencing responses. In contrast, PPV P1 $\Delta \mathrm{HC}$ was completely unable to initiate an infection process in the susceptible host $N$. benthamiana (Fig. 4), demonstrating the key relevance of an active RSS for potyviral viability. This strict requirement was also recently reported for an RSS-deficient Turnip mosaic virus expressing an inactive HCPro, which only infected $N$. benthamiana when the tombusviral RSS P19 was exogenously supplied (Garcia-Ruiz et al. 2010). Several reasons might explain the different degrees of requirement for RNA silencing suppression activity of Potyvirus spp. and other viruses: i) higher rates of replication and movement could allow some viruses to escape antiviral silencing more easily; ii) although all the compared viruses replicate in the cytoplasm, their genomic RNAs could differ in the accessibility by the silencing effector machinery; iii) the larger size of the genomic potyviral RNAs could make them more susceptible to the RNA silencing action; and iv) the possibility that, in the absence of the main RSS in some viral systems, other viral factors could help the virus to evade plant antiviral defenses cannot be ruled out.

The ability of PPV P1P1b, in which HCPro has been replaced by CVYV P1b, to infect very efficiently two plant species of the Nicotiana genus (Fig. 2) demonstrates that, in spite of the strict requirement for RNA silencing suppression of Potyvirus spp., these viruses do not depend on the specific activity of a particular RSS. HCPro is a multifunctional protein (Syller
2005), which interacts with a number of host proteins (AlaPoikela et al. 2011; Anandalakshmi et al. 2000; Cheng et al. 2008; Dielen et al. 2011; Endres et al. 2010; Guo et al. 2003; Jin et al. 2007a and b). Our results also demonstrate that, in spite of the lack of sequence similarity, CVYV P1b is able to supply all essential functions of HCPro. However, the lower accumulation of P1P1b compared with P1HC (wild-type PPV) in Nicotiana spp. (Figs. 2 and 3) appears not to be due to an unspecific weakness of the silencing suppression activity of CVYV P1b, because P1P1b suppresses silencing even more strongly than $\mathrm{P} 1 \mathrm{HC}$ in agroinfiltration assays (Fig. 5). Thus, it is likely that either some specific coupling of the RNA silencing suppression of HCPro with other viral processes, such as viral replication, cannot be exactly mimicked by the CVYV $\mathrm{P} 1 \mathrm{~b}$ antisilencing activity, or a silencing suppression-unrelated activity of HCPro cannot be fully supplied by the heterologous protein. It is also interesting to remark that, in spite of the lower virus accumulation, some disease symptoms are more severe in plants infected with P1b-expressing viruses than in those infected with the wild-type virus (Fig. 2). A number of RSS have been shown to be targets for plant defense responses other than RNA silencing. For instance, HCPro of Potato virus $Y$ (Moury et al. 2011) and other RSS, such as P38 of Turnip crinkle virus (Ren et al. 2000) and P126 of Tobacco mosaic virus (Padgett et al. 1997), are elicitors of hypersensitive response (HR) and viral resistance mediated by resistance genes; and P6 of CaMV (Kiraly et al. 1999), 2b of Tomato aspermy virus (Li et al. 1999), and P19 of TBSV (Chu et al. 2000) induce HR-like necrotic symptoms. Thus, a defensive reaction of the plants elicited by P1b may be the cause of the strengthened symptoms caused by PPV P1P1b (rather than a direct effect of virus multiplication), and could be one of the factors accounting for the lower accumulation of the P1b-expressing chimera compared with wild-type PPV.

The P1 protein has been shown to be an accessory factor that facilitates the genome amplification of the potyvirus Tobacco etch virus (Verchot and Carrington 1995). Some evidence suggest that P1 could enhance the RNA silencing suppression activity of HCPro (Kasschau and Carrington 1998; Pruss et al. 1997; Rajamaki et al. 2005; Valli et al. 2006). P1 is also a nonessential factor in PPV infection but deletion of the P1 gene notably debilitates PPV (unpublished results), because deletion of P1 in the chimera P1P1b causes a drop in virus accumulation and movement (Fig. 3). P1 did not enhance the silencing suppression activity of $\mathrm{P} 1 \mathrm{~b}$ in the agroinfiltration system; however, P1 deletion facilitated plant recovery at late stages of infection (Fig. 3B), suggesting that P1 could be contributing to efficient RNA silencing suppression. Surprisingly, CVYV P1a not only does not reproduce the positive contribution of the natural P1 to PPV infection but it is clearly deleterious for the virus in $N$. benthamiana. PPV P1aP1b was able to infect $N$. benthamiana, although much less efficiently than the P1-deficient PPV P1b virus, and the P1aP1b-infected plant is cleared of virus a few weeks after inoculation (Fig. 3). Similarly, PPV P1aHC also infects, very mildly, $N$. benthamiana. In contrast with PPV P1, upstream CVYV P1a sequences drastically disturbed the RNA silencing suppression activity of P1b (Fig. 5) and HCPro, and this disturbance is likely the cause of the detrimental effect of P1a in PPV infection. Although we do not know how P1a interferes with the silencing suppression activity of $\mathrm{P} 1 \mathrm{~b}$, transient expression experiments provided valuable clues. Agroinfiltration of bacteria expressing P1a-P1b yielded much lower P1b protein levels than that expressing P1-P1b, even though the strong RSS P19 was coexpressed to ensure P1b-independent silencing suppression activity (Fig. 6), and unprocessed $\mathrm{P} 1 \mathrm{a}-\mathrm{P} 1 \mathrm{~b}$ product, but not $\mathrm{P} 1-\mathrm{P} 1 \mathrm{~b}$, was detected in the infiltrated leaves (Fig. 6). Although low P1b accumulation 
and inefficient P1a self-cleavage might be unrelated, the previous observation that P1 self-cleavage depends on plant proteins (Verchot et al. 1992) suggests a scenario in which proper folding of the precursor polyprotein, assisted by specific host factors, results in processing, whereas the incorrectly folded precursor is degraded. This would explain why, in contrast with its detrimental effect in the $N$. benthamiana infection, P1a enhances PPV amplification in cucumber (Fig. 8). The inefficiency of the agroinfiltration system in cucumber has prevented us from testing this hypothesis; however, the fact that P1a-P1b polyprotein precursor was not detected in $C$. sativus plants infected with either P1aP1b chimera (data not shown) or wild-type CVYV (Valli et al. 2008) supports this idea. In any case, these results are in agreement with the important role of P1 proteins in host specificity of Potyvirus spp. that has been previously suggested (Noa-Carrazana et al. 2006; Salvador et al. 2008; Valli et al. 2007).

Previous reports have revealed the possibility that specific HCPro activities contribute to virus adaptation to particular hosts (Sáenz et al. 2002). We show now that, whereas P1bexpressing PPV replicates efficiently in $N$. benthamiana, it infects very poorly the natural PPV host $P$. persica (Fig. 7), suggesting that the function of $\mathrm{P} 1 \mathrm{~b}$ could also be host specific. In agreement with this assumption, expression of CVYV P1b enhanced local PPV replication in leaves of $C$. sativus (Fig. 8). The suppression activity of HCPro and P1b is thought to be mediated by binding to siRNAs, which are expected to be similar in different plant species. Therefore, if the different behavior of HCPro-expressing and P1b-expressing PPV in different hosts is the consequence of host-specific features of the RNA silencing suppression activities of HCPro and P1b, it would be necessary to hypothesize that siRNA binding per se is not enough to suppress antiviral RNA silencing, and host factors contribute to establish an effective silencing suppression activity. This hypothesis needs to be tested in silencing suppression experimental systems which, unfortunately, are still not available for $P$. persica and $C$. sativus; thus, we cannot rule out the possibility that RNA silencing-unrelated functions of HCPro and P1b could be involved in the host specificity shown by the different PPV variants.

Finally, the P1aP1b PPV chimera only forms small foci inside the inoculated area of cucumber leaves (Fig. 8), despite expressing $\mathrm{P} 1 \mathrm{a}$ and $\mathrm{P} 1 \mathrm{~b}$ proteins from the cucumber-infecting CVYV. This observation reveals the existence of specific virus genetic factors required for cucumber infection outside the P1a and P1b coding sequences, in agreement with earlier reports showing that host range determinants are extensively spread throughout the PPV genome (Salvador et al. 2008). Plant-virus interactions affected by these specific determinants are largely unknown and should be the subject of further research.

\section{MATERIALS AND METHODS}

\section{Plant hosts.}

Agroinfiltration assays were performed in N. benthamiana plants. Viral infectivity assays were performed in $N$. benthamiana, $N$. clevelandii, C. sativus Albatroz RZ F1, and P. persica GF305 plants. Plants were grown in a greenhouse maintained under $16 \mathrm{~h}$ of light with supplementary illumination at 19 to $23^{\circ} \mathrm{C}$.

\section{Plasmids.}

A partial PPV clone (p35SeNOSB) carrying the cDNA corresponding to the $5^{\prime}$ region of the genome of the PPV-R isolate (nucleotides 1 to 3,628 that correspond to the $5^{\prime}$ untranslated region [UTR] and $\mathrm{P} 1, \mathrm{HCPro}, \mathrm{P} 3$, and $6 \mathrm{~K} 1$ cistrons) cloned between the CaMV $35 \mathrm{~S}$ promoter and the NOS terminator
(López-Moya and García 2000), in which the first AUG of the large open reading frame was mutated and the second AUG was engineered to display an NcoI restriction site (SimónBuela et al. 1997), was used as backbone to generate intermediate cDNA clones coding for different mutated PPV 5' genomic regions (p35S-P1 $\Delta \mathrm{HC}$, p35S-P1P1b, p35S-P1aP1b, and p35S-P1b).

The gene splicing via overlap extension method (Horton et al. 1989) was used to generate p35S-P1 $\Delta$ HC and p35S-P1P1b. Primers and templates for polymerase chain reactions (PCR) used to construct these clones are listed in Supplementary Tables $\mathrm{S} 1$ and $\mathrm{S} 2$. Hence, p35S-P1 $\Delta \mathrm{HC}$ was obtained by replacing the NcoI-DraIII fragment of p35SeNOSB that encodes the $\mathrm{N}$-terminal region of the PPV polyprotein, with the corresponding fragment from PCR3, which codes for PPV P1-P3 and lacks the HCPro coding sequence. p35S-P1P1b was obtained by inserting an NcoI-BamHI fragment from PCR6 plus a BamHI-DraIII fragment from PCR9, which together code for PPV P1-CVYV P1b-PPV P3, in p35SeNOSB digested with NcoI and DraIII. p35S-P1P1b clones carrying RK68,69AA, C89A, or C93A mutant versions of CVYV P1b were obtained by replacing the NcoI-BamHI fragment from p35S-P1P1b that codes for P1-P1b with the corresponding fragments from PCR11, PCR13, and PCR15, respectively. The CVYV P1aP1b-coding sequence lacking its internal NcoI site was obtained by using the mutagenesis method of Herlitze and Koenen (1990). The resulting PCR product (PCR18), digested with $N c o$ I and BamHI, was used to substitute for the corresponding fragment of p35S-P1P1b, yielding p35S-P1aP1b. p35S-P1b was obtained by replacing the NcoI-SexAI fragment from $\mathrm{p} 35 \mathrm{SeNOSB}$ with the corresponding fragment from PCR19, which codes for CVYV P1b. Because SexI cleaves into the PPV HCPro-coding sequence 9 nucleotides away from its $3^{\prime}$ end, the CVYV P1b protein encoded by p35S-P1b is fused to the last 3 amino acids of PPV HCPro.

$\mathrm{P} 1 \Delta \mathrm{HC}, \mathrm{P} 1 \mathrm{P} 1 \mathrm{~b}, \mathrm{P} 1 \mathrm{~b}$, and $\mathrm{P} 1 \mathrm{aP} 1 \mathrm{~b}$ full-length clones were obtained by substituting the $35 \mathrm{~S}-\mathrm{P} 1 \Delta \mathrm{HC}$, p35S-P1P1b, p35S$\mathrm{P} 1 \mathrm{~b}$, and $\mathrm{p} 35 \mathrm{~S}-\mathrm{P} 1 \mathrm{aP} 1 \mathrm{~b} X \mathrm{X} a \mathrm{I}-\mathrm{DraIII}$ fragments that code for the $5^{\prime}$ region of the viral genome preceded by the CaMV $35 \mathrm{~S}$ promoter for the corresponding fragment of pICPPV-NKGFPn (P. Sáenz, M. R. Fernández-Fernández, and J. A. García, unpublished results), a plasmid derived from pICPPV-NK-GFP (Fernandez-Fernandez et al. 2001) in which the enhanced GFP had been replaced by the wild-type GFP from Aequorea victoria (Fig. 1).

The gene splicing via overlap extension method (Horton et al. 1989) was also used to generate a P1aHC full-length clone. It was obtained by replacing the Bsu36I-DraIII fragment of $\mathrm{P} 1 \mathrm{aP} 1 \mathrm{~b}$ infectious clone with the corresponding fragment from PCR27, which codes for CVYV P1a and HCPro-P3 from PPV.

A partial PPV clone (p35S5'DNOS) carrying the cDNA corresponding to the $5^{\prime}$ region of the genome of the PPV-D isolate (nucleotides 1 to 2,923 that include the 5' UTR and P1, HCPro, and P3 cistrons) cloned between the CaMV 35S promoter and the NOS terminator (Salvador 2008) was used as backbone to generate an intermediate cDNA clone coding for a chimeric PPV-CVYV 5' genomic region (p35S-P1DP1b). This chimeric clone was constructed by using the gene splicing via overlap extension method (Horton et al. 1989). p35S-P1DP1b was obtained by inserting a $C p o \mathrm{I}-V s p \mathrm{I}$ fragment from PCR21 plus a VspI-Pst I fragment from PCR24 which, together, code for PPV-D P1-CVYV P1b-PPV-D P3, in p35S5'DNOS digested with $C p o I$ and PstI. The P1P1b-BD full-length clone (Fig. 1) was constructed by a triple ligation of the Bpu1102IPstI fragment that encodes P1-P1b from p35S-P1DP1b, and SacI-Bpu1102I and PstI-SacI fragments from pICPPV-5'BD GFP (Salvador et al. 2008). 
pBINPPV-NK-GFP, which contains a full-length cDNA copy of the PPV genome cloned in pBin19 (Bevan 1984) under the control of the CaMV 35 S promoter (Lucini 2004), was used as parental plasmid to generate infectious binary vectors for the different recombinant viruses. These clones were constructed by replacing the $S c a \mathrm{I}-X h o \mathrm{I}$ fragment from pBINPPVNK-GFP that includes the nucleotide 1 to 6,770 sequence of PPV preceded by the CaMV $35 \mathrm{~S}$ promoter, with the corresponding fragments from P1P1b, P1aP1b, or P1b.

pBIN-P1HC, a pBin19-derivative carrying the cDNA corresponding to the $5^{\prime}$ region of the PPV-R genome (M. O. Delgadillo, J. A. García, and C. Simón-Mateo, unpublished results), was the parental plasmid in the construction of pBINP1P1b, pBIN-P1aP1b, pBIN-P1b, and pBIN-P1aHC, which were used in the agroinfiltration assays. pBIN-P1P1b, pBIN$\mathrm{P} 1 \mathrm{aP} 1 \mathrm{~b}$, and $\mathrm{pBIN}-\mathrm{P} 1 \mathrm{~b}$ were obtained by replacing the pBINP1HC ScaI-XbaI fragment that codes for the 5' region of the viral genome preceded by the CaMV $35 \mathrm{~S}$ promoter, with the corresponding fragments from p35S-P1P1b, p35S-P1aP1b, or p35S-P1b. pBIN-P1aHC was obtained by replacing the pBINP1HC XmaI-SnaBI fragment that also codes for the 5' region of the viral genome preceded by the CaMV 35S promoter, with the corresponding fragments from the PlaHC full-length clone.

A. tumefaciens $\mathrm{C} 58 \mathrm{C} 1$ strain carrying p35S:GFP (Haseloff et al. 1997) plus pCH32 (Hamilton et al. 1996), p35S:GF-IR (Schwach et al. 2005), and pBIN61:P19 (Voinnet et al. 2003) were kindly provided by D. Baulcombe (University of Cambridge, United Kingdom).

\section{Biolistic inoculation.}

The Helios Gene Gun System (Bio-Rad, Hercules, CA, U.S.A.) was used for biolistic inoculation. Microcarrier cartridges were prepared with $1.0-\mu \mathrm{m}$ gold particles coated with the different plasmids at a DNA loading ratio of $2 \mu \mathrm{g} / \mathrm{mg}$ of gold and a microcarrier loading of $0.5 \mathrm{mg} / \mathrm{shooting}$. Helium pressure of 7 and 10 bars were used for shooting Nicotiana and $P$. persica plants, respectively.

\section{Agroinfiltration and GFP imaging.}

$N$. benthamiana and $C$. sativus plants were infiltrated with A. tumefaciens strain $\mathrm{C} 58 \mathrm{C} 1$ carrying the indicated plasmids, as previously described (Valli et al. 2006). The GFP fluorescence was monitored under long-wavelength UV light (Black Ray model B 100 AP) and photographed with a Nikon D1X digital camera equipped with a 62E 022 filter. For amplified visualization of fluorescent areas, leaves were examined with a Leica MZ FLIII epifluorescence microscope equipped with a filter that had an excitation window at $425 / 460 \mathrm{~nm}$ and a barrier filter at $480 \mathrm{~nm}$ and were photographed with an Olympus DP70 digital camera.

\section{Western blot assays.}

Tissue samples of infected leaves were harvested under UV light from GFP-expressing areas, while tissue samples of noninfected leaves were taken from equivalent areas. Preparation of protein samples, sodium dodecyl sulfate polyacrylamide gel electrophoresis, and electroblotting were done as previously described (Valli et al. 2006). Specific proteins were detected using anti-HCPro rabbit serum, anti-P1b rabbit serum, or anti$\mathrm{CP}$ rabbit serum as primary antibody, and horseradish peroxidase-conjugated goat anti-rabbit immunoglobulin G (Jackson ImmunoResearch, West Grove, PA, U.S.A.) as secondary reagent. The immunostained proteins were visualized by enhanced chemiluminiscence detection with a LifeABlot kit (Euroclone S.p.A., Siziano, Italy). Ponceau red staining was used to check the global protein content of the samples.
RNA extraction and Northern blot analysis.

Samples of large and small RNAs were prepared from agroinfiltrated leaf tissue and subjected to Northern blot analysis as previously described (Valli et al. 2006). GFP siRNAs were detected with ${ }^{32} \mathrm{P}$-labeled GF and $\mathrm{P}$ riboprobes, which were prepared by transcription with SP6 RNA polymerase from SacIIlinearized pGEMT-GF and pGEMT-P, respectively. These plasmids contain the nucleotides 4 to 403 (GF) and 404 to 717 (P) of the GFP gene cloned in pGEM-T.

\section{ACKNOWLEDGMENTS}

We thank H. García-Ruiz for critical reading of the manuscript, D. Baulcombe for providing GFP and P19 expression vectors, Rijk Zwaan Iberica (Almería, Spain) for supplying cucumber seeds, and E. Dominguez for technical assistance. This work was supported by grants BIO201018541 from Spanish MICINN, SAL/0185/2006 from Comunidad de Madrid, and KBBE-204429 from European Union. A. Valli was a recipient of an I3P fellowship from CSIC-Fondo Social Europeo.

\section{LITERATURE CITED}

Ala-Poikela, M., Goytia, E., Haikonen, T., Rajamaki, M.-L., and Valkonen, J. P. T. 2011. Helper component proteinase of genus Potyvirus is an interaction partner of translation initiation factors eIF(iso)4E and eIF4E that contains a 4E binding motif. J. Virol. 85:6784-6794.

Anandalakshmi, R., Pruss, G. J., Ge, X., Marathe, R., Mallory, A. C. Smith, T. H., and Vance, V. B. 1998. A viral suppressor of gene silencing in plants. Proc. Natl. Acad. Sci. U.S.A. 95:13079-13084.

Anandalakshmi, R., Marathe, R., Ge, X., Herr, J. M., Jr., Mau, C., Mallory, A., Pruss, G., Bowman, L., and Vance, V. B. 2000. A calmodulin-related protein that suppresses posttranscriptional gene silencing in plants. Science 290:142-144.

Berger, P. H., Hunt, A. G., Domier, G. M., Hellman, G. M., Stram, Y., Thornbury, D. W., and Pirone, T. P. 1989. Expression in transgenic plants of a viral gene product that mediates insect transmission of potyviruses. Proc. Natl. Acad. Sci. U.S.A. 86:8402-8406.

Bevan, M. 1984. Binary Agrobacterium vectors for plant transformation. Nucleic Acids Res. 12:8711-8721.

Brigneti, G., Voinnet, O., Li, W. X., Ji, L. H., Ding, S. W., and Baulcombe, D. C. 1998. Viral pathogenicity determinants are suppressors of transgene silencing in Nicotiana benthamiana. EMBO (Eur. Mol. Biol. Organ.) J. 17:6739-6746.

Burgyán, J. 2008. Role of silencing suppressor proteins. Methods Mol. Biol. 451:69-79.

Cheng, Y. Q., Liu, Z. M., Xu, J., Zhou, T., Wang, M., Chen, Y. T., Li, H. F., and Fan, Z. F. 2008. HC-Pro protein of sugar cane mosaic virus interacts specifically with maize ferredoxin-5 in vitro and in planta. J. Gen. Virol. 89:2046-2054.

Chu, M., Desvoyes, B., Turina, M., Noad, R., and Scholthof, H. B. 2000. Genetic dissection of tomato bushy stunt virus p19-protein-mediated host-dependent symptom induction and systemic invasion. Virology 266:79-87.

Cronin, S., Verchot, J., Haldeman-Cahill, R., Schaad, M. C., and Carrington, J. C. 1995. Long-distance movement factor: A transport function of the potyvirus helper component proteinase. Plant Cell 7:549-559.

Diaz-Pendon, J. A., Li, F., Li, W. X., and Ding, S. W. 2007. Suppression of antiviral silencing by cucumber mosaic virus $2 \mathrm{~b}$ protein in Arabidopsis is associated with drastically reduced accumulation of three classes of viral small interfering RNAs. Plant Cell 19:2053-2063.

Dielen, A. S., Sassaki, F. T., Walter, J., Michon, T., Menard, G., Pagny, G., Krause-Sakate, R., Maia Ide, G., Badaoui, S., Le Gall, O., Candresse, T., and German-Retana, S. 2011. The 20S proteasome alpha5 subunit of Arabidopsis thaliana carries an RNase activity and interacts in planta with the lettuce mosaic potyvirus HcPro protein. Mol. Plant Pathol. 12:137-150.

Ding, S. W. 2010. RNA-based antiviral immunity. Nat. Rev. Immunol. 10:632-644.

Endres, M. W., Gregory, B. D., Gao, Z., Foreman, A. W., Mlotshwa, S., Ge, X., Pruss, G. J., Ecker, J. R., Bowman, L. H., and Vance, V. 2010. Two plant viral suppressors of silencing require the ethylene-inducible host transcription factor RAV2 to block RNA silencing. PLoS Pathog. 6:e1000729. Published online.

Fellers, J. P., Seifers, D., Ryba-White, M., and Martin, T. J. 2009. The complete genome sequence of Triticum mosaic virus, a new wheatinfecting virus of the High Plains. Arch. Virol. 154:1511-1515. 
Fernandez-Fernandez, M. R., Mourino, M., Rivera, J., Rodriguez, F., Plana-Duran, J., and Garcia, J. A. 2001. Protection of rabbits against rabbit hemorrhagic disease virus by immunization with the VP60 protein expressed in plants with a potyvirus-based vector. Virology 280:283-291.

Gal-On, A., and Raccah, B. 2000. A point mutation in the FRNK motif of the potyvirus helper component-protease gene alters symptom expression in cucurbits and elicits protection against the severe homologous virus. Phytopathology 90:467-473.

Garcia-Ruiz, H., Takeda, A., Chapman, E. J., Sullivan, C. M., Fahlgren, N., Brempelis, K. J., and Carrington, J. C. 2010. Arabidopsis RNAdependent RNA polymerases and dicer-like proteins in antiviral defense and small interfering RNA biogenesis during Turnip mosaic virus infection. Plant Cell 22:481-496.

Giner, A., Lakatos, L., Garcia-Chapa, M., Lopez-Moya, J. J., and Burgyan, J. 2010. Viral protein inhibits RISC activity by Argonaute binding through conserved WG/GW motifs. PLoS Pathog. 6:e1000996. Published online.

Guo, D., Spetz, C., Saarma, M., and Valkonen, J. P. 2003. Two potato proteins, including a novel RING finger protein (HIP1), interact with the potyviral multifunctional protein HCPro. Mol. Plant-Microbe Interact. 16:405-410

Hamilton, C. M., Frary, A., Lewis, C., and Tanksley, S. D. 1996. Stable transfer of intact high molecular weight DNA into plant chromosomes. Proc. Natl. Acad. Sci. U.S.A. 93:9975-9979.

Haseloff, J., Siemering, K. R., Prasher, D. C., and Hodge, S. 1997. Removal of a cryptic intron and subcellular localization of green fluorescent protein are required to mark transgenic Arabidopsis plants brightly. Proc. Natl. Acad. Sci. U.S.A. 94:2122-2127.

Herlitze, S., and Koenen, M. 1990. A general and rapid mutagenesis method using polymerase chain reaction. Gene 91:143-147.

Horton, R. M., Hunt, H. D., Ho, S. N., Pullen, J. K., and Pease, L. R. 1989. Engineering hybrid genes without the use of restriction enzymes: Gene splicing by overlap extension. Gene 77:61-68.

Janssen, D., Martin, G., Velasco, L., Gomez, P., Segundo, E., Ruiz, L., and Cuadrado, I. M. 2005. Absence of a coding region for the helper component-proteinase in the genome of cucumber vein yellowing virus, a whitefly-transmitted member of the Potyviridae. Arch. Virol. 150:14391447.

Jin, Y. S., Ma, D. Y., Dong, J. L., Jin, J. C., Li, D. F., Deng, C. W., and Wang, T. 2007a. HC-Pro protein of Potato Virus $Y$ can interact with three Arabidopsis 20S proteasome subunits in planta. J. Virol. 81:1288112888.

Jin, Y. S., Ma, D. Y., Dong, J. L., Li, D. F., Deng, C. W., Jin, J. C., and Wang, T. 2007b. The HC-Pro protein of Potato virus Y interacts with NtMinD of tobacco. Mol. Plant- Microbe Interact. 20:1505-1511.

Kasschau, K. D., and Carrington, J. C. 1998. A counterdefensive strategy of plant viruses: Suppression of posttranscriptional gene silencing. Cell 95:461-470

Kasschau, K. D., Cronin, S., and Carrington, J. C. 1997. Genome amplification and long-distance movement functions associated with the central domain of tobacco etch potyvirus helper component-proteinase. Virology 228:251-262.

Kiraly, L., Cole, A. B., Bourque, J. E., and Schoelz, J. E. 1999. Systemic cell death is elicited by the interaction of a single gene in Nicotiana clevelandii and gene VI of Cauliflower mosaic virus. Mol. PlantMicrobe Interact. 12:919-925.

Lakatos, L., Csorba, T., Pantaleo, V., Chapman, E. J., Carrington, J. C., Liu, Y. P., Dolja, V. V., Calvino, L. F., López-Moya, J. J., and Burgyán, J. 2006. Small RNA binding is a common strategy to suppress RNA silencing by several viral suppressors. EMBO (Eur. Mol. Biol. Organ.) J. 25:2768-2780.

Li, H. W., Lucy, A. P., Guo, H. S., Li, W. X., Ji, L. H., Wong, S. M., and Ding, S. W. 1999. Strong host resistance targeted against a viral suppressor of the plant gene silencing defence mechanism. EMBO (Eur. Mol. Biol. Organ.) J. 18:2683-2691.

Li, W. M., Hilf, M. E., Webb, S. E., Baker, C. A., and Adkins, S. 2008 Presence of $\mathrm{P} 1 \mathrm{~b}$ and absence of HC-Pro in Squash vein yellowing virus suggests a general feature of the genus Ipomovirus in the family Potyviridae. Virus Res. 135:213-219.

López-Moya, J. J., and García, J. A. 2000. Construction of a stable and highly infectious intron-containing cDNA clone of plum pox potyvirus and its use to infect plants by particle bombardment. Virus Res. 68:99107

López-Moya, J. J., Valli, A., and García, J. A. 2009. Potyviridae. In: Encyclopedia of Life Sciences. N. S. Iacobellis, A. Collmer, S. W. Hutcheson, J. W. Mansfield, C. E. Morris, J. Murillo, N. W. Schaad, D. E. Stead, G. Surico, and M. Ullrich, eds. Kluwer Academic, Dordrecht, The Netherlands. Online publication.

Lucini, C. 2004. Expresión de proteínas heterólogas en plantas por medio del virus de la sharka (PPV). Universidad Politécnica de Madrid, Madrid.

Mbanzibwa, D. R., Tian, Y. P., Mukasa, S. B., and Valkonen, J. P. T. 2009. Cassava brown streak virus (Potyviridae) encodes a putative Maf/HAM1 pyrophosphatase implicated in reduction of mutations and a P1 proteinase that suppresses RNA silencing but contains no HC-Pro. J. Virol. 83:6934-6940.

Moissiard, G., and Voinnet, O. 2004. Viral suppression of RNA silencing in plants. Mol. Plant Pathol. 5:71-82.

Moury, B., Caromel, B., Johansen, E., Simon, V., Chauvin, L., Jacquot, E., Kerlan, C., and Lefebvre, V. 2011. The helper component proteinase cistron of Potato virus $Y$ induces hypersensitivity and resistance in potato genotypes carrying dominant resistance genes on chromosome IV. Mol. Plant-Microbe Interact. 24:787-797.

Noa-Carrazana, J. C., González-de-León, D., and Silva-Rosales, L. 2006. Molecular characterization of a severe isolate of Papaya ringspot virus in Mexico and its relationship with other isolates. Virus Genes 35:109117.

Omarov, R., Sparks, K., Smith, L., Zindovic, J., and Scholthof, H. B. 2006. Biological relevance of a stable biochemical interaction between the tombusvirus-encoded P19 and short interfering RNAs. J.Virol. 80:3000-3008.

Padgett, H. S., Watanabe, Y., and Beachy, R. N. 1997. Identification of the TMV replicase sequence that activates the $\mathrm{N}$ gene-mediated hypersensitive response. Mol. Plant-Microbe Interact. 10:709-715.

Pruss, G., Ge, X., Shi, X. M., Carrington, J. C., and Vance, V. B. 1997. Plant viral synergism: The potyviral genome encodes a broad-range pathogenicity enhancer that transactivates replication of heterologous viruses. Plant Cell 9:859-868.

Qiu, W. P., Park, J. W., and Scholthof, H. B. 2002. Tombusvirus p19-mediated suppression of virus-induced gene silencing is controlled by genetic and dosage features that influence pathogenicity. Mol. PlantMicrobe Interact. 15:269-280.

Rajamaki, M. L., Kelloniemi, J., Alminaite, A., Kekarainen, T., Rabenstein, F., and Valkonen, J. P. 2005. A novel insertion site inside the potyvirus P1 cistron allows expression of heterologous proteins and suggests some P1 functions. Virology 342:88-101.

Ren, T., Qu, F., and Morris, T. J. 2000. HRT gene function requires interaction between a NAC protein and viral capsid protein to confer resistance to Turnip crinkle virus. Plant Cell 12:1917-1926.

Rojas, M. R., Zerbini, F. M., Allison, R. F., Gilbertson, R. L., and Lucas, W. J. 1997. Capsid protein and helper component proteinase function as potyvirus cell-to-cell movement proteins. Virology 237:283-295.

Roth, B. M., Pruss, G. J., and Vance, V. B. 2004. Plant viral suppressors of RNA silencing. Virus Res. 102:97-108.

Sáenz, P., Cervera, M. T., Dallot, S., Quiot, L., Quiot, J. B., Riechmann, J. L., and García, J. A. 2000. Identification of a pathogenicity determinant of Plum pox virus in the sequence encoding the C-terminal region of protein P3+6K. J. Gen. Virol. 81:557-566.

Sáenz, P., Salvador, B., Simón-Mateo, C., Kasschau, K. D., Carrington, J. C., and García, J. A. 2002. Host-specific involvement of the HC protein in the long-distance movement of potyviruses. J. Virol. 76:1922-1931.

Salvador, B. 2008. Pathogenicity and host range determinants in plum pox virus infection: A role for P1 protein. Universidad Autónoma de Madrid, Madrid.

Salvador, B., Delgadillo, M. O., Saénz, P., García, J. A., and Simón-Mateo, C. 2008. Identification of Plum pox virus pathogenicity determinants in herbaceous and woody hosts. Mol. Plant-Microbe Interact. 21:20-29.

Schwach, F., Vaistij, F. E., Jones, L., and Baulcombe, D. C. 2005. An RNA-dependent RNA polymerase prevents meristem invasion by Potato virus $X$ and is required for the activity but tot the production of a systemic silencing signal. Plant Physiol. 138:1842-1852.

Simón-Buela, L., Guo, H. S., and García, J. A. 1997. Cap-independent leaky scanning as the mechanism of translation initiation of a plant viral genomic RNA. J. Gen. Virol. 78:2691-2699.

Soosaar, J. L. M., Burch-Smith, T. M., and Dinesh-Kumar, S. P. 2005. Mechanisms of plant resistance to viruses. Nat. Rev. Microbiol. 3:789798.

Stenger, D. C., Young, B. A., Qu, F., Morris, T. J., and French, R. 2007. Wheat streak mosaic virus lacking helper component-proteinase is competent to produce disease synergism in double infections with Maize chlorotic mottle virus. Phytopathology 97:1213-1221.

Susaimuthu, J., Tzanetakis, I. E., Gergerich, R. C., and Martin, R. R. 2008. A member of a new genus in the Potyviridae infects Rubus. Virus Res. 131:145-151

Syller, J. 2005. The roles and mechanisms of helper component proteins encoded by potyviruses and caulimoviruses. Physiol. Mol. Plant Pathol. 67:119-130

Szittya, G., Molnar, A., Silhavy, D., Hornyik, C., and Burgyan, J. 2002. Short defective interfering RNAs of tombusviruses are not targeted but 
trigger post-transcriptional gene silencing against their helper virus. Plant Cell 14:359-372.

Tatineni, S., Ziems, A. D., Wegulo, S. N., and French, R. 2009. Triticum mosaic virus: A distinct member of the family Potyviridae with an unusually long leader sequence. Phytopathology 99:943-950.

Valli, A., Martín-Hernández, A. M., López-Moya, J. J., and García, J. A. 2006. RNA silencing suppression by a second copy of the P1 serine protease of Cucumber vein yellowing ipomovirus (CVYV), a member of the family Potyviridae that lacks the cysteine protease HCPro. J. Virol. 80:10055-10063.

Valli, A., López-Moya, J. J., and García, J. A. 2007. Recombination and gene duplication in the evolutionary diversification of $\mathrm{P} 1$ proteins in the family Potyviridae. J. Gen. Virol. 88:1016-1028.

Valli, A., Dujovny, G., and García, J. A. 2008. Protease activity, self interaction, and small interfering RNA binding of the silencing suppressor P1b from Cucumber vein yellowing ipomovirus. J. Virol. 82:974-986.

Valli, A., López-Moya, J. J., and García, J. A. 2009. RNA silencing and its suppressors in the plant-virus interplay. In: Encyclopedia of Life Sciences. N. S. Iacobellis, A. Collmer, S. W. Hutcheson, J. W. Mansfield, C. E. Morris, J. Murillo, N. W. Schaad, D. E. Stead, G. Surico, and M.
Ullrich, eds. Kluwer Academic, Dordrecht, The Netherlands. Online publication.

Valli, A., Oliveros, J. C., Molnar, A., Baulcombe, D., and Garcia, J. A 2011. The specific binding to 21-nt double-stranded RNAs is crucial for the anti-silencing activity of Cucumber vein yellowing virus $\mathrm{P} 1 \mathrm{~b}$ and perturbs endogenous small RNA populations. RNA 17:1148-1158.

Verchot, J., and Carrington, J. C. 1995. Evidence that the potyvirus P1 proteinase functions in trans as an accessory factor for genome amplification. J. Virol. 69:3668-3674.

Verchot, J., Herndon, K. L., and Carrington, J. C. 1992. Mutational analysis of the tobacco etch potyviral $35-\mathrm{kDa}$ proteinase: Identification of essential residues and requirements for autoproteolysis. Virology 190:298-306

Voinnet, O., Rivas, S., Mestre, P., and Baulcombe, D. 2003. An enhanced transient expression system in plants based on suppression of gene silencing by the p19 protein of Tomato bushy stunt virus. Plant J. 33:949956.

Ziebell, H., Payne, T., Berry, J. O., Walsh, J. A., and Carr, J. P. 2007. A Cucumber mosaic virus mutant lacking the $2 \mathrm{~b}$ counter-defence protein gene provides protection against wild-type strains. J. Gen. Virol. $88: 2862-2871$. 